\title{
Article \\ Comparative Study of Sample-Preparation Techniques for Quantitative Analysis of the Mineral Composition of Humic Substances by Inductively Coupled Plasma Atomic Emission Spectroscopy
}

\author{
Evgeniya A. Karpukhina *(D), Elena A. Vlasova, Dmitry S. Volkov (D) and Mikhail A. Proskurnin (D) \\ Department of Chemistry, Lomonosov Moscow State University, Leninskie Gory 1-3, 119991 Moscow, Russia; \\ vsmesle@gmail.com (E.A.V.); dmsvolkov@gmail.com (D.S.V.); proskurnin@gmail.com (M.A.P.) \\ * Correspondence: karpukhina.evgeniya@gmail.com
}

Citation: Karpukhina, E.A.; Vlasova, E.A.; Volkov, D.S.; Proskurnin, M.A. Comparative Study of Sample-Preparation Techniques for Quantitative Analysis of the Mineral Composition of Humic Substances by Inductively Coupled Plasma Atomic Emission Spectroscopy. Agronomy 2021, 11, 2453. https://doi.org/ 10.3390 /agronomy11122453

Academic Editor: Mercedes del Río Celestino

Received: 21 October 2021

Accepted: 29 November 2021

Published: 30 November 2021

Publisher's Note: MDPI stays neutral with regard to jurisdictional claims in published maps and institutional affiliations.

Copyright: (c) 2021 by the authors. Licensee MDPI, Basel, Switzerland. This article is an open access article distributed under the terms and conditions of the Creative Commons Attribution (CC BY) license (https:// creativecommons.org/licenses/by/ $4.0 /)$.

\begin{abstract}
Five sample-preparation techniques were compared to quantify 31 elements in coal humic substances (HS) by ICP-AES from the viewpoints of complete isolation and speciation of elements. They include, for bulk composition, preparation of an aqueous colloidal HS solution followed by direct injection of the sample without decomposition and ashing followed by metaborate fusion; for element speciation, preparation of an aqueous colloidal HS solution followed by centrifugation and direct analysis without decomposition for water-soluble species; treatment with boiling nitric acid; and microwave-assisted treatment with nitric acid at $250{ }^{\circ} \mathrm{C}$ for acid-isolated species. The results of analysis significantly depend on the selected method of sample preparation due to specific features of HS, the simultaneous presence of many inorganic components in wide concentration ranges, and a significant fraction of the organic matrix; therefore, the total mineral composition of HS, both macroand microcomponents, requires a combination of decomposition methods.
\end{abstract}

Keywords: humic substances; mineral composition; element speciation; inductively coupled plasma atomic emission spectroscopy

\section{Introduction}

Humic substances (HS) are used today in various applications: main components of plant fertilizers, plant/animal growth regulators, and environmental detoxifiers [1-6]. Moreover, many studies deal with HS as promising medicines. Recent reviews [2,3,7-10] describe antibacterial, detoxifying, analgesic, antioxidant, antiviral, metabolic, antiarthritic, immunomodulating, and anti-inflammatory properties of HS-i.e, humic acids (HA), humates, and fulvic acids (FA) and their derivatives. In addition, HS and their derivatives are the subjects of discussion in the treatment of cancer [9] and HIV [11,12]. It is believed that HS-based drugs and products are an excellent source of essential microelements, while due to chelating properties, they remove toxic elements from the body. However, despite such a significant potential, all of the aspects of their possible biomedical activities have not been studied yet. The pharmacological effects of HS-based drugs are currently being tested either on animal models or using human biomaterial (blood serum, tissues) in vitro only $[8,10,12]$. The hazardous elements in HS have not been fully considered, either.

Still, the increased interest in HS in biomedicine has led to many commercially available vitamin-mineral complexes, dietary supplements, food products, beverages, and cosmetics $[7,9,13]$. In these preparations, HS enter the human body directly through the digestive system or direct skin contact. However, if these samples contain hazardous components, this may cause allergic reactions and health problems. Thus, the issues of quality and safety assurance of HS and HS-based products have already become truly relevant, and all the components of HS should be taken into consideration. 
This research aims to develop approaches to analyzing the HS mineral part. At present, much attention is paid to HS organic components, while almost all HS samples contain specific amounts of inorganic substances. These inorganic components are still present in the final sample after separating HS from coal, peat, or soil. Due to many possible binding sites and high polydispersity, $\mathrm{HS}$ can form various relatively stable metal complexes; however these compounds cannot be described by individual thermodynamic stability constants [14]. In addition, mineral components of HS preparations are partly unbound by humic substances, as they are either in an insoluble form or in excess of organic binding centers of HS. Therefore, the determination of all elements present in HS is topical. Moreover, to predict HS toxicity and bioavailability, it is crucial to know the total content of elements and their speciation [15-18].

Today, the mineral composition of HS preparations has not been sufficiently studied. As far as we are concerned, no studies deal with the quality assurance and reliability of measurements and the development of specific analytical methods. A large part of HS research on metals features their complexation and sorption properties and usually focuses on either a single metal or a group of up to five elements at large [9,18-22]. Furthermore, the authors do not analyze HS initial mineral composition but only evaluate its sorption parameters to some cations.

Another group of studies is focused on HS mineral composition not as a whole but rather on individual HS samples and their preparations. These include HS from natural sources, dietary supplements, and food products. Most of these studies deal with HS in soils, waters, and bottom and coastal deposits of rivers and lakes [23-37]. Among HS decomposition methods and metal separation methods, the approaches most often involve mineral acids $\left(\mathrm{HNO}_{3}, \mathrm{HCl}, \mathrm{HF}, \mathrm{HClO}_{4}\right)$ or their mixtures, hydrogen peroxide, organic solvents, or metal binding to EDTA. The HS analysis may be carried out without sample preparation to directly analyze drinks containing fulvic acids [13], however most studies require sample preparation. Still, approaches to sample preparation are not compared.

Metals in HS are determined by AAS [23,24,26,27], ICP-AES [25,28,31,32,35,37], MPAES [13], X-ray fluorescence [29], NAA [24,33,34], or voltammetric techniques [24]. The common drawback is a narrow set of test elements, despite the wide range of elements that these methods can determine. Furthermore, the studies lack unified decomposition methods for HS. The most detailed analysis of the mineral composition in HS was carried out in study Hirata [25], which analyzed coastal sediments, and HS extracted from them for 17 metals and then compared element contents. Despite the large amount of data on metal contents in HS, the development of analytical procedures was not considered. There are no studies with a wide range of metals investigated and their species analyzed, which should be considered when assessing HS sample safety.

Thus, this study aims to develop an approach to quantitatively analyze HS mineral composition by ICP-AES using various sample preparation techniques. 31 elements most often found in natural objects (soils, coals) were chosen to determine the complete composition of humates. For the first time, five sample preparation approaches for HS were compared for quantitative ICP-AES analysis. To determine the bulk composition, we selected (1) preparation of an aqueous colloidal solution of HS followed by direct injection of the sample without decomposition and (2) ashing HS samples followed by decomposition by fusion with $\mathrm{LiBO}_{2}$. To evaluate various species of elements, we used (1) preparation of an aqueous colloidal solution of HS followed by direct centrifugation analysis without decomposition to analyze water-soluble species of elements; (2) treatment with boiling nitric acid; and (3) treatment with nitric acid at $250{ }^{\circ} \mathrm{C}$ using a microwave autoclave for assessing acid-isolated species of elements.

\section{Materials and Methods}

\subsection{HS Samples}

The following samples of humic acid salts were selected: "Life Force" (sodium humate, Saratov, Russia), "Sakhalin" (potassium humate, Moscow, Russia), and "Powhumus" 
(potassium humate, Grevenbroich, Germany). All three samples are isolated from brown coal. The "Powhumus" and "Life Force" humates are powders. "Sakhalin" is a liquid, so the sample was pre-dried to a powder.

\subsection{Reference Materials of Water and Soil}

Reference materials SSP-WW1 Batch 115 of Wastewater (13 elements); and SPS-SW2 Batch 132 of Surface Waters (45 elements); 3 reference standards of soils ( 2 national reference standards and one inter-laboratory comparative sample (ILCS)) were used for verification of the developed method.

\subsection{Reagents}

Water (specific resistance, $18.2 \mathrm{M} \Omega \times \mathrm{cm}$ ) from a Milli-Q purification system (Merck Millipore, Darmstadt, Germany) was used throughout. A multielement standard solution of 24 elements ICP-AM-6 (Ag, Al, Sb, Ba, Be, B, Cd, Ca, Cr, Co, Cu, Fe, Pb, Li, Mg, Mn, $\mathrm{Ni}, \mathrm{K}, \mathrm{Si}, \mathrm{Na}, \mathrm{Sr}, \mathrm{Tl}, \mathrm{V}, \mathrm{Zn}$ with the concentration of each element $100 \mathrm{mg} \mathrm{L}^{-1}$; High-Purity Standards, North Charleston, SC, USA), multielement standard solution of 4 elements ICP-AM-15 (Na, K, Ca, Mg with the concentration of each element 10,000 mg L ${ }^{-1}$; HighPurity Standards, North Charleston, SC, USA), single element standard solutions of P, S, Si with concentration $1000 \mathrm{mg} \mathrm{L}^{-1}$ (Inorganic Ventures, Christiansburg, VA, USA), single element standard solution of Fe with concentration 10,000 $\mathrm{mg} \mathrm{L}^{-1}$ (High-Purity Standards, North Charleston, SC, USA) were used for calibration. Concentration ranges of elements in the calibration solutions were $0.04-20 \mathrm{mg} \mathrm{L}^{-1}$ for $\mathrm{Ag}, \mathrm{Al}, \mathrm{As}, \mathrm{B}, \mathrm{Ba}, \mathrm{Be}, \mathrm{Cd}, \mathrm{Co}, \mathrm{Cr}$, $\mathrm{Cu}, \mathrm{Li}, \mathrm{Mn}, \mathrm{Mo}, \mathrm{Ni}, \mathrm{Pb}, \mathrm{Sb}$, Se, Sn, Sr, Ti, V, W, and $\mathrm{Zn} ; 0.04-400 \mathrm{mg} \mathrm{L}^{-1}$ for $\mathrm{Ca}, \mathrm{Fe}, \mathrm{K}$, $\mathrm{Mg}$, Na; $0.4-200 \mathrm{mg} \mathrm{L}^{-1}$ for $\mathrm{P}, \mathrm{S} ; 10-200 \mathrm{mg} \mathrm{L}^{-1}$ for $\mathrm{Si}$ ). A scandium standard solution $\left(10,000 \mathrm{mg} \mathrm{L}^{-1}\right.$; Inorganic Ventures, Christiansburg, VA, USA) was used as an internal standard $\left(20 \mathrm{mg} \mathrm{L}^{-1}\right)$. Nitric acid (69\%, PA-ACS-ISO grade, Panreac, Barcelona, Spain) was used as a diluent for calibration standards. An ammonium hydroxide solution (25\%, Reakhim, Moscow, Russia) was used for preparing rinse solutions. Lithium metabolite $\mathrm{LiBO} 2$ (cp) (Reakhim, Moscow, Russia) was used for the fusion.

\subsection{Moisture Analysis}

The moisture content was determined with an HG63 infrared thermogravimetric moisture analyzer (Mettler-Toledo AG, Greifensee, Switzerland). The automatic shutdown criterion "weight loss per unit time" was used (drying ended automatically when the average mass loss per unit of time fell below a present value). All humate concentrations were recalculated based on water content. For each sample, three replicates were made, and then the average moisture value was calculated.

\subsection{Samples for Direct Analysis by ICP-AES}

Three series of solutions with an approximate concentration of $0.2,2$, and $20 \mathrm{~g} \mathrm{~L}^{-1}$ were prepared, for which weighted samples of $0.1,0.1$, and $1 \mathrm{~g}$ (with an accuracy of $0.0001 \mathrm{~g}$ ) were dissolved in deionized water in 500.0, 50.00, and $50.00 \mathrm{~mL}$ volumetric flasks, respectively. Solutions were adjusted to the mark with deionized water. Part of the solutions was centrifuged for $15 \mathrm{~min}$ at $4000 \mathrm{rpm}$. Next, measurements were made for solutions without centrifugation and supernatants after centrifugation.

\subsection{Extraction of Elements by Boiling Nitric Acid at Atmospheric Pressure}

A solution of $5 \mathrm{M}$ nitric acid was preliminarily prepared. For this $500-600 \mathrm{~mL}$ of deionized water (specific resistance, $18.2 \mathrm{M} \Omega \times \mathrm{cm}$ ) was poured in a 1-L volumetric flask, and $310 \mathrm{~mL}$ of concentrated $\mathrm{HNO}_{3}(69 \%$, ACS-ISO grade, Panreac, Barcelona, Spain), measured with a cylinder, was poured into it. The volume of the solution was brought to the mark with deionized water, stirred and cooled to room temperature.

A 2.0-mL sample was taken into a $50-\mathrm{mL}$ volumetric flask on an analytical balance. Next, $10 \mathrm{~mL}$ (by a cylinder) of $5 \mathrm{M} \mathrm{HNO}_{3}$ was added. The sample was carefully wetted 
with rotational movements and then stirred. The flask was closed with a glass funnel and put on an electric hot plate to render slow boiling. After $3 \mathrm{~h}$, the flask was cooled to room temperature. After cooling, the solution was filtered through a quantitative ashless paper filter, grade 40 into a A-class 50-mL volumetric flask. The sample was washed on the filter with deionized water, and the volume was adjusted to the mark with deionized water. In the resulting acid extract, the metal contents were determined.

\subsection{Extraction of Elements with Nitric Acid at $250{ }^{\circ} \mathrm{C}$ in a Microwave Oven}

An Ultraclave III microwave system (Milestone GMBH, Sorisole, Italy) was used for sample acid digestion. Samples of $0.25 \mathrm{~g}$ (precision, $0.1 \mathrm{mg}$ ) were placed in a PTFE digestion tube of the Ultraclave III system, then $5 \mathrm{~mL}$ of HNO3 (69\%, ACS-ISO grade, Panreac, Barcelona, Spain) was added. The tube was heated up to $250{ }^{\circ} \mathrm{C}$, held for $60 \mathrm{~min}$ at $250{ }^{\circ} \mathrm{C}$, and pressure $120 \mathrm{bar}$, then cooled. After depressurization, the solution was transferred to a $25-\mathrm{mL}$ polypropylene volumetric flask, diluted with deionized water, and analyzed.

\subsection{Ashing}

Samples of HS of 5-8 g were placed in platinum crucibles, heated in a SNOL 6.7/1100 muffle furnace (Snol Ltd., Utena, Lithuania) to a temperature of $800{ }^{\circ} \mathrm{C}$, and held for $6 \mathrm{~h}$, and periodically the crucible was stirred gently with forceps without touching the sample until the formation of light grey or light brown ash. After ashing, the crucibles were cooled in a desiccator with calcium chloride and weighed; the ash content in the samples was calculated with the account of humidity. The resulting ash was further used for fusion.

\subsection{Fusion of Samples}

Portions of $2 \mathrm{~g}$ of $\mathrm{LiBO}_{2}$ were added to weighed portions of $\mathrm{HS}$ ash of $0.5 \mathrm{~g}$ in carbon crucibles, mixed, and put into a furnace heated to $1100{ }^{\circ} \mathrm{C}$ for $5-8 \mathrm{~min}$. Then, the melt was stirred using nickel forceps (Bochem, Weilburg, Germany) and kept for 3-4 min until a uniform melt was formed. Then, the crucibles were removed from the furnace, and the melt was immediately poured into a $250-\mathrm{mL}$ Teflon beaker containing ca. $100 \mathrm{~mL}$ of $5 \% \mathrm{HNO}_{3}$. The resulting hot solutions were quickly quantitatively transferred to A-class 250-mL volumetric flasks, Teflon beakers were washed three times with deionized water, and the washing waters were collected in the same flasks. Then, the flasks were placed in an ultrasonic bath and treated until the melt was wholly dissolved, periodically stirring vigorously. After complete dissolution, the flasks were removed from the bath, cooled, and the volumes were adjusted to the mark. The resulting solutions were used for ICP-AES analysis.

\subsection{ICP-AES Analysis}

Element analysis was performed with an ICP-AES 720 spectrometer (Agilent Technologies, Santa Clara, CA, USA) with an axial quartz torch with an inner 1.8-mm diameter injector tube (Agilent Technologies, Santa Clara, CA, USA), a double-pass glass cyclonic spray chamber (Agilent Technologies, Santa Clara, CA, USA), a OneNeb nebulizer (Agilent Technologies, Santa Clara, CA, USA), and a trident internal standard kit (Glass Expansion, Pocasset, MA, USA). For sample introduction, an SPS3 autosampler was used. A peristaltic pump used the white/white polyvinyl chloride pump tube for feeding and the blue/blue pump tube for the drain. A Sc $\left(20 \mathrm{mg} \mathrm{L}^{-1}\right)$ internal standard solution was added online (an orange/blue polyvinyl chloride pump tube) to increase the accuracy of measurements. Conditions of ICP-AES measurements are summed up in Table 1. Results were collected and processed with ICP Expert II software 2.0.5 (Agilent Technologies, Santa Clara, CA, USA). Emission lines from Table 2 were used for measurements. All lines were measured simultaneously (a MultiCal mode). Linear or quadratic functions were used for calibration. 
Table 1. Measurement parameters by ICP-AES.

\begin{tabular}{|c|c|}
\hline Parameters & Values \\
\hline \multicolumn{2}{|c|}{ Conditions } \\
\hline Power $(\mathrm{kW})$ & 1.50 \\
\hline Plasma-forming flow $\left(\mathrm{L} \mathrm{min}^{-1}\right)$ & 18.0 \\
\hline Axial flow $\left(\mathrm{L} \mathrm{min}^{-1}\right)$ & 1.50 \\
\hline Nebulizer flow $\left(\mathrm{L} \mathrm{min}^{-1}\right)$ & 1.00 \\
\hline Replicate time (s) & 10 \\
\hline Stabilization time (s) & 30 \\
\hline \multicolumn{2}{|c|}{ Sample-injection parameters } \\
\hline Sample time delay (s) & 25 \\
\hline Pump rate (rpm) & 12 \\
\hline Washing time (s) & 10 \\
\hline Number of replicates & 4 \\
\hline
\end{tabular}

Table 2. Wavelengths (nm) for ICP-AES measurements.

\begin{tabular}{|c|c|}
\hline Elements & Emission Lines, $\mathrm{nm}$ \\
\hline $\mathrm{Ag}$ & $328.07,338.29$ \\
\hline $\mathrm{Al}$ & $308.22,394.40,396.15$ \\
\hline As & $188.98,193.70,197.20,234.98$ \\
\hline $\mathrm{B}$ & $182.58,208.89,208.96,249.68$ \\
\hline $\mathrm{Ba}$ & $230.42,233.53,455.40,493.41,614.17$ \\
\hline $\mathrm{Be}$ & $234.86,249.47,313.04,313.11$ \\
\hline $\mathrm{Ca}$ & $315.89,317.93,393.37,396.85,422.67$ \\
\hline $\mathrm{Cd}$ & 228.80 \\
\hline Co & $230.79,231.160,237.863,238.892,258.03$ \\
\hline $\mathrm{Cr}$ & $267.716,276.259,276.653,313.205$ \\
\hline $\mathrm{Cu}$ & $324.754,327.400$ \\
\hline $\mathrm{Fe}$ & $238.204,239.563,258.590,259.940,263.105$ \\
\hline $\mathrm{K}$ & $404.72,766.49,769.90$ \\
\hline $\mathrm{Li}$ & $610.37,670.78$ \\
\hline $\mathrm{Mg}$ & $277.98,279.55,279.80,280.27,285.21,383.23,383.83$ \\
\hline $\mathrm{Mn}$ & $257.61,259.37,260.57,293.305,293.931,294.92$ \\
\hline Mo & $202.03,281.62,284.82,289.10,313.26,379.83$ \\
\hline $\mathrm{Na}$ & $568.82,589.00,589.59$ \\
\hline $\mathrm{Ni}$ & $216.56,221.65,227.02,230.299,231.604,231.10$ \\
\hline $\mathrm{P}$ & $185.88,213.62,214.91$ \\
\hline $\mathrm{Pb}$ & 220.35 \\
\hline $\mathrm{S}$ & $180.67,181.97,182.56$ \\
\hline $\mathrm{Sb}$ & $206.83,217.58,231.15$ \\
\hline $\mathrm{Sc}$ & $357.63,424.68,361.38,357.25,335.37$ \\
\hline Se & 196.03 \\
\hline $\mathrm{Si}$ & $250.69,251.43,251.61,252.41,252.85,288.16$ \\
\hline Sn & $189.925,283.998,317.503,326.233$ \\
\hline $\mathrm{Sr}$ & $346.445,407.771,416.179,421.552$ \\
\hline $\mathrm{Ti}$ & $334.188,334.941,336.122,337.280,368.520$ \\
\hline $\mathrm{V}$ & $289.265,292.401,311.837$ \\
\hline W & $207.91,216.63,222.59,222.96,224.88$ \\
\hline $\mathrm{Zn}$ & $202.55,206.200,213.86,334.56$ \\
\hline
\end{tabular}

For each HS sample, three replicates were taken for each decomposition method. For each sample, two replicates were performed. Then, $4 \mathrm{~mL}$ of solution was needed for each replicate. Then the obtained data were averaged. The quality control of the analysis was carried out using a control sample with a known concentration of each element (20 mg L $\mathrm{m}^{-1} \mathrm{P}$ and S; $40 \mathrm{mg} \mathrm{L}^{-1} \mathrm{Fe}$; $200 \mathrm{mg} \mathrm{L}^{-1} \mathrm{Ca}, \mathrm{K}, \mathrm{Mg}$, and $\mathrm{Na} ; 400 \mathrm{mg} \mathrm{L}^{-1} \mathrm{Si}$; and 
$1 \mathrm{mg} \mathrm{L}^{-1}$ of the rest). The control sample was prepared from standard solutions other than calibration solutions.

Single-use polypropylene tubes for ICP-AES measurements and PTFE autoclaves for microwave digestions were used to minimize sample contamination. Before sample extraction or digestion, all glasses and polypropylene vessels were thoroughly rinsed using concentrated acids and deionized water. Blank samples were treated using all stages of digestion for test samples and contained all reagents. Levels of all test elements in the blank samples were below their detection limits.

\subsection{Other Equipment}

Volumes were taken with Eppendorf Pro mechanical automatic dispensers $(10.00 \pm 0.04)-(100 \pm 1) \mu \mathrm{L},(100 \pm 1)-(1000 \pm 8) \mu \mathrm{L}$, and $(500 \pm 15)-(5000.0 \pm 37.5) \mu \mathrm{L}$. Powders were weighed with an Ohaus Discovery DV114C analytical balance (Nänikon, Switzerland; accuracy, $0.0001 \mathrm{~g}$; weighing limit, $120 \mathrm{~g}$ ). To dissolve the preparations, we used a GRAD 28-35 ultrasonic bath (ZAO Grad-Technology, Moscow, Russia). Centrifugation was carried out in an SM-50 centrifuge (ELMI Ltd., Riga, Latvia) in 14-mL polypropylene test tubes. Solutions were prepared in B-class 500 and $250 \mathrm{~mL}$ and A-class $50 \mathrm{~mL}$ volumetric glass flasks and 10 and $50 \mathrm{~mL}$ polypropylene test tubes. Another glassware (funnels, tubes) is standard chemically resistant laboratory glass. Samples (powders) were selected using stainless steel spatulas. Centrifugation was carried out.

\subsection{Data Treatment}

The obtained data were exported to MS Office Excel Professional Plus 2010 (32-bit, version no. 14.0.5128.5000), and basic calculations were also performed there. Element content diagrams were built using OriginPro 2016 software (64-bit, b9.3.226).

\section{Results and Discussion}

Using various methods of sample preparation with ICP-AES analysis for each sample, the results were obtained for $\mathrm{Ag}$, $\mathrm{Al}, \mathrm{As}, \mathrm{B}, \mathrm{Ba}, \mathrm{Be}, \mathrm{Ca}, \mathrm{Cd}, \mathrm{Co}, \mathrm{Cr}, \mathrm{Cu}, \mathrm{Fe}, \mathrm{K}, \mathrm{Li}, \mathrm{Mg}$, $\mathrm{Mn}, \mathrm{Mo}, \mathrm{Na}, \mathrm{Ni}, \mathrm{P}, \mathrm{Pb}, \mathrm{S}, \mathrm{Sb}, \mathrm{Se}, \mathrm{Si}, \mathrm{Sn}, \mathrm{Sr}, \mathrm{Ti}, \mathrm{V}, \mathrm{W}$, and $\mathrm{Zn}$ (Table 3 and Figures S1-S5, Supplementary Materials). Ag, $\mathrm{Sb}$, and Se were not detected in any sample at the level of $0.6 \mathrm{mg} \mathrm{kg}^{-1}$. The lithium and boron contents for solutions obtained by fusion with lithium metaborate are excluded from consideration.

Table 3. Content of elements by different types of sample preparation approaches for "Powhumus", "Sakhalin", and "Life Force" HS: an aqueous colloidal solution of HS (Dir), fusion with $\mathrm{LiBO}_{2}$ (Ash), an aqueous colloidal solution of $\mathrm{HS}$ followed by centrifugation (Cen), treatment with boiling nitric acid (Acid), treatment with nitric acid at $250{ }^{\circ} \mathrm{C}$ using a microwave autoclave (MW).

\begin{tabular}{|c|c|c|c|c|c|c|c|c|c|c|c|c|c|c|c|c|}
\hline \multirow{2}{*}{ Element } & \multirow{2}{*}{$\begin{array}{c}\text { Sample } \\
\text { Technique }\end{array}$} & \multicolumn{5}{|c|}{ Powhumus } & \multicolumn{5}{|c|}{ Sakhalin } & \multicolumn{5}{|c|}{ Life Force } \\
\hline & & Dir & Ash & Cen & Acid & MW & Dir & Ash & Cen & Acid & MW & Dir & Ash & Cen & Acid & MW \\
\hline $\mathrm{Al}$ & $\mathrm{g} \mathrm{kg}^{-1}$ & 25 & 27 & 14 & 6.9 & 25 & 24 & 33 & 16 & 12 & 25 & 3.6 & 9.6 & 2.9 & 4.3 & 8.4 \\
\hline As & $\mathrm{mg} \mathrm{kg}^{-1}$ & 27 & - & 17 & 11 & 24 & 3.8 & - & 2.4 & 1.4 & 2.8 & 1.3 & - & 1.1 & 0.56 & 0.88 \\
\hline B & $\mathrm{mg} \mathrm{kg}^{-1}$ & 12 & - & 5.2 & 3.8 & 12 & 8.1 & - & 6.8 & 5.6 & 13 & 8.1 & - & 6.8 & 5.6 & 13 \\
\hline $\mathrm{Ba}$ & $\mathrm{mg} \mathrm{kg}^{-1}$ & 76 & 88 & 42 & 37 & 83 & 281 & 413 & 200 & 281 & 335 & 66 & 105 & 63 & 71 & 79 \\
\hline $\mathrm{Be}$ & $\mathrm{mg} \mathrm{kg}^{-1}$ & 4.2 & 3.6 & 3.9 & 3.7 & 4.1 & 1.4 & 1.3 & 1.2 & 1.3 & 1.3 & 0.74 & 0.63 & 0.67 & 0.82 & 0.82 \\
\hline $\mathrm{Ca}$ & $\mathrm{g} \mathrm{kg}^{-1}$ & 9.8 & 9.6 & 9.4 & 9.0 & 10 & 6.4 & 8.1 & 5.8 & 6.2 & 7.0 & 4.9 & 5.0 & 4.6 & 5.0 & 5.5 \\
\hline $\mathrm{Cd}$ & $\mathrm{mg} \mathrm{kg}^{-1}$ & 0.60 & 0.07 & 0.45 & 0.32 & 0.72 & 0.61 & 0.08 & 0.52 & 0.39 & 0.75 & 0.27 & 0.05 & 0.23 & 0.16 & 0.37 \\
\hline Co & $\mathrm{mg} \mathrm{kg}^{-1}$ & 9.0 & 6.9 & 7.7 & 6.4 & 9.4 & 16 & 18 & 13 & 8 & 16 & 4.6 & 3.3 & 4.3 & 3.1 & 5.9 \\
\hline $\mathrm{Cr}$ & $\mathrm{mg} \mathrm{kg}^{-1}$ & 42 & 44 & 31 & 21 & 42 & 22 & 29 & 17 & 11 & 25 & 4.4 & 7.2 & 3.8 & 3.6 & 6.1 \\
\hline $\mathrm{Cu}$ & $\mathrm{mg} \mathrm{kg}^{-1}$ & 30 & 26 & 28 & 11 & 30 & 32 & 50 & 27 & 8.1 & 33 & 4.0 & 7.3 & 3.7 & 2.1 & 4.6 \\
\hline $\mathrm{Fe}$ & $\mathrm{g} \mathrm{kg}^{-1}$ & 9.1 & 11 & 6.6 & 5.4 & 11 & 15 & 20 & 12 & 7.4 & 16 & 2.7 & 3.2 & 2.4 & 1.9 & 3.0 \\
\hline K & $\mathrm{g} \mathrm{kg}^{-1}$ & 83 & 104 & 81 & 88 & 86 & 79 & 125 & 76 & 80 & 76 & 1.7 & 5.8 & 1.7 & 0.53 & 0.75 \\
\hline
\end{tabular}


Table 3. Cont.

\begin{tabular}{|c|c|c|c|c|c|c|c|c|c|c|c|c|c|c|c|c|}
\hline \multirow{2}{*}{ Element } & \multirow{2}{*}{$\begin{array}{c}\text { Sample } \\
\text { Technique }\end{array}$} & \multicolumn{5}{|c|}{ Powhumus } & \multicolumn{5}{|c|}{ Sakhalin } & \multicolumn{5}{|c|}{ Life Force } \\
\hline & & Dir & Ash & Cen & Acid & MW & Dir & Ash & Cen & Acid & MW & Dir & Ash & Cen & Acid & MW \\
\hline $\mathrm{Li}$ & $\mathrm{mg} \mathrm{kg}^{-1}$ & 29 & - & 8.9 & 5.5 & 32 & 14 & - & 2.0 & 2.3 & 14 & 1.2 & - & 0.18 & 0.82 & 2.8 \\
\hline $\mathrm{Mg}$ & $\mathrm{g} \mathrm{kg}^{-1}$ & 1.2 & 1.2 & 0.80 & 0.95 & 1.3 & 2.0 & 2.5 & 1.5 & 1.6 & 2.2 & 0.81 & 0.94 & 0.71 & 1.0 & 1.0 \\
\hline Mn & $\mathrm{mg} \mathrm{kg}^{-1}$ & 15 & 16 & 8.7 & 12 & 18 & 52 & 66 & 47 & 47 & 57 & 48 & 57 & 43 & 54 & 62 \\
\hline Mo & $\mathrm{mg} \mathrm{kg}^{-1}$ & 3.2 & - & 1.7 & 0.35 & 0.52 & 0.78 & - & 0.26 & - & - & 9.6 & - & 9.4 & 0.6 & 0.6 \\
\hline $\mathrm{Na}$ & $\mathrm{g} \mathrm{kg}^{-1}$ & 2.4 & 4.6 & 2.3 & 2.2 & 3.4 & 1.3 & 2.2 & 1.2 & 1.0 & 1.5 & 59 & 72 & 67 & 69 & 72 \\
\hline $\mathrm{Ni}$ & $\mathrm{mg} \mathrm{kg}^{-1}$ & 38 & 37 & 32 & 27 & 37 & 51 & 59 & 49 & 42 & 50 & 23 & 27 & 21 & 18 & 25 \\
\hline $\mathrm{P}$ & $\mathrm{g} \mathrm{kg}^{-1}$ & 0.12 & 0.18 & 0.05 & 0.04 & 0.11 & 1.8 & 2.4 & 1.0 & 1.9 & 2.1 & 0.05 & 0.07 & 0.04 & 0.05 & 0.05 \\
\hline $\mathrm{Pb}$ & $\mathrm{mg} \mathrm{kg}^{-1}$ & 4.0 & - & 2.7 & 2.6 & 5.5 & 4.9 & - & 3.2 & 2.6 & 6.5 & 2.3 & - & 2.4 & 1.3 & 3.2 \\
\hline$S$ & $\mathrm{~g} \mathrm{~kg}^{-1}$ & 2.6 & 0.18 & 2.4 & 1.3 & 3.0 & 1.6 & 0.25 & 1.4 & 0.73 & 1.5 & 1.3 & 0.14 & 1.3 & 0.82 & 2.3 \\
\hline $\mathrm{Si}$ & $\mathrm{g} \mathrm{kg}^{-1}$ & 19 & 31 & 6.6 & 1.0 & 0.30 & 22 & 35 & 4.0 & 0.65 & 0.20 & 2.8 & 14.2 & 1.1 & 0.71 & 0.27 \\
\hline Sn & $\mathrm{mg} \mathrm{kg}^{-1}$ & 16 & 27 & 13 & 9.0 & 20 & 8.6 & 20 & 6.4 & 4.0 & 9.6 & 2.2 & 8.5 & 2.1 & 1.7 & 3.3 \\
\hline $\mathrm{Sr}$ & $\mathrm{mg} \mathrm{kg}^{-1}$ & 59 & 63 & 45 & 43 & 67 & 578 & 874 & 356 & 644 & 767 & 35 & 43 & 32 & 37 & 44 \\
\hline $\mathrm{Ti}$ & $\mathrm{g} \mathrm{kg}^{-1}$ & 1.9 & 2.5 & 0.58 & 0.05 & 0.11 & 1.1 & 1.8 & 0.60 & 0.13 & 0.13 & 0.19 & 0.36 & 0.15 & 0.05 & 0.17 \\
\hline $\mathrm{V}$ & $\mathrm{mg} \mathrm{kg}^{-1}$ & 65 & 77 & 36 & 34 & 68 & 26 & 37 & 11 & 7.1 & 28 & 7.8 & 9.7 & 6.7 & 6.3 & 8.6 \\
\hline W & $\mathrm{mg} \mathrm{kg}^{-1}$ & 12 & 31 & 7.7 & 4.1 & 12.2 & 13 & 33 & 9.2 & 4.6 & 14 & 6.5 & 24 & 6.2 & 3.1 & 11 \\
\hline $\mathrm{Zn}$ & $\mathrm{mg} \mathrm{kg}^{-1}$ & 24 & 30 & 16 & 20 & 24 & 40 & 30 & 33 & 34 & 41 & 11 & 16 & 9.0 & 27 & 14 \\
\hline
\end{tabular}

\subsection{Features of Sample Preparation for HS Analysis}

HS significantly differ from soils by a more significant organic-matter fraction. Therefore, HS preparations require different approaches to decomposition. The specific features of HS are that, on the one hand, the sample mainly consists of organic compounds and contains a significant fraction of inorganic components. On the other hand, HA salts are well soluble in water, which allows their direct analysis. However, it should be borne in mind that HS samples, especially not subjected to deep purification and demineralization with $\mathrm{HCl} / \mathrm{HF}$, often contain co-extractable mineral components such as clay minerals and quartz [38]. Previously, we found aluminosilicate components in such HS by FTIR [39]. These mineral components are water-insoluble, but absorb HS well on their surface [40]. Thus, aqueous samples without purification will inevitably be colloidal solutions with insoluble components. One of the tasks of this study was to assess (i) to what extent it is possible to use direct injection of such solutions without decomposition into an ICP-AES spectrometer and (ii) what elements remain in the sediment.

Metaborate fusion is a versatile method for the macrostructure of silicates [41] and many other materials. In samples with high organic content, preliminary dry ashing is usually necessary because metaborate fusion is carried out in platinum or graphite crucibles. In platinum crucibles, the large carbon matrix of HS may lead to irreversible crucible damage due to the formation of platinum carbide. In graphite crucibles, the analysis conditions are reductive; therefore, preliminary conversion of all species to oxides is necessary. Moreover, in both cases, carbon in the sample substantially complicates the formation of the borates of the rest of the elements. Thus, preliminary dry ashing contributes to the loss of many trace elements in the form of volatile compounds. Therefore, this sample preparation method for HS cannot be the sole approach, regardless of the sensitivity of the subsequent instrumental determination.

Acid decomposition in a microwave oven requires a much higher percentage of oxidant acids to oxidize the organic part of HS and a smaller percentage of hydrofluoric acid due to the smaller amounts of the mineral part. However, hydrofluoric acid leads to the formation of significant amounts of difficultly soluble fluorides of calcium and aluminum, leading to the coprecipitation of microamounts of a few elements. There are methods to counteract this based on excess boric acid and extra microwave heating. However, apart from complexity, this method does not always wholly decompose the formed fluorides; therefore, we did not use it in this study. Thus, we selected microwave decomposition using concentrated nitric acid only. In combination with a high temperature 
of $250{ }^{\circ} \mathrm{C}$, this acid reached a pressure of ca. 120 bar and did not need any other oxidizing agents. However, it is noteworthy that not all serial microwave ovens provide such high temperatures and pressures.

Decomposition with concentrated nitric acid by boiling at atmospheric pressure was used for comparison and as a more affordable alternative to microwave-assisted decomposition. Cold-acid extracts from HS cannot be obtained since HS precipitate from a strongly acidic environment, and metals precipitate with them. Therefore, producing nitric-acid extracts by boiling, which is used to make extracts from soils, was selected.

\subsection{Determination of Bulk Composition by Direct Injection of Colloidal Solutions of HS without Decomposition}

The presence of colloidal particles in the composition of colloidal HS solutions is not a serious obstacle to their direct analysis by ICP-AES. This method is used for clays [42] and has been successfully used to analyze nanodiamond suspensions [43]. Nevertheless, its application to each new object requires a comparison with more classical approaches based on the complete decomposition of samples.

For many elements, the results for colloidal solutions and solutions obtained by microwave-assisted decomposition differ slightly. However, the contents of such elements as silicon and aluminium, which are the main components of clay minerals, are significantly lower than for fusion, which indicates that ICP-AES conditions are insufficient for the decomposition of clay particles of HS. Thus, the determination of bulk Si and Al by direct injection does not give satisfactory results.

On the other hand, the results of the determination of $\mathrm{As}, \mathrm{Be}, \mathrm{Co}$, and $\mathrm{Li}$ are comparable with the results by microwave decomposition, and the contents of $\mathrm{Al}, \mathrm{Cr}, \mathrm{Fe}, \mathrm{Mg}, \mathrm{Mn}$, and $\mathrm{Ni}$ are comparable with the results by fusion (the difference is not more than $15 \%$ ). Moreover, the direct-injection method gives the results for sodium and potassium as the main counterions for HA that are consistent with other methods.

Of particular note are As and Mo. In the case of As, direct injection has an advantage over dry ashing, as there is no danger of volatilizing arsenic. For Mo, nitric acid likely leads to the precipitation of molybdenum oxides and their deposition on the remaining undecomposed clay particles. In the case of metaborate fusion, the molybdenum content in the solution is below the applicable concentration range.

As HS form colloidal solutions in water, this approach to sample preparation makes it possible to estimate many bulk elements except those present as large particles. As a result of their sedimentation, the concentrations of corresponding elements are underestimated, which is seen when they are compared with nitric acid and fusion methods.

It should be noted that direct injection of HS solutions without decomposition into an ICP-AES spectrometer requires a slightly alkaline ammonia solution as a washing solution for the sample-introduction system. The internal standard solution must also be prepared without acidification. Otherwise, HA precipitates upon online mixing with the internal standard in an acidic medium or sprayed in a spray chamber; thus, their determination is impossible. Moreover, this would lead to clogging the spectrometer sample-introduction system. A part of cations can be adsorbed on sedimented particles and lead to underestimated results, in addition, the sedimented particles can clog the thin capillary of the atomizer and damage the system. Overall, the results obtained allow us to conclude that the direct injection of colloidal solutions of HS can be used for rapid and relatively accurate assessment of the content of almost all inorganic elements with due regard to the above precaution conditions.

\subsection{Bulk Composition by Dry Ashing Followed by Metaborate Fusion}

In dry ashing followed by metaborate fusion, the highest contents were obtained for $\mathrm{Al}, \mathrm{Ba}, \mathrm{Cr}, \mathrm{Si}, \mathrm{Sn}, \mathrm{Sr}, \mathrm{Ti}$, and $\mathrm{W}$ for all samples and $\mathrm{Cu}, \mathrm{Fe}$ for "Powhumus" and "Sakhalin" samples. Thus, fusion provides the most reliable macronutrient content, especially $\mathrm{Si}$, $\mathrm{Al}$, and Ti. These are the main rock-forming elements that form the minerals extracted together with HS; the remaining elements of this list are likely to exist in their composition 
as impurities. Moreover, tungsten compounds in significant amounts (more than half of all tungsten by weight) are chemically and/or physically bound to the aluminosilicate part of HS samples and are not subject to acid decomposition.

On the other hand, in the case of $\mathrm{As}, \mathrm{Cd}, \mathrm{Pb}$, and $\mathrm{S}$, a significant underestimation of the results is observed compared to other decomposition methods. This result is associated with the volatile character of the compounds of the first three elements, especially at the stage of dry ashing. Sulfur as sulfates is very stable and not volatile, however, it is reduced to elemental sulfur and sublimated under the conditions of graphite crucibles. Therefore, the results of determining these elements by borate fusion are unreliable. The determination of $\mathrm{Li}$ and $\mathrm{B}$ is impossible for obvious reasons.

As for Mo, the lack of results for this element is explained by the method sensitivity, not by the decomposition conditions. From the viewpoint of the chemistry of molybdenum, fusion should give the highest transfer of this element to soluble compounds; however, to increase the sensitivity of its determination, it is necessary to either increase the weight and apply preconcentration methods in ICP-AES or use ICP-MS as a more sensitive method.

As a whole, for main elements, especially those in large quantities, dry ashing with borate fusion gives the most reliable information on their content and can be recommended as the primary sample preparation method for the analysis of the total macro-composition of HS. At the same time, ICP-AES is the most versatile and accurate among all other quantitative analysis methods. On the other hand, ICP-MS would require a significant dilution to eliminate the matrix influence of metaborate, and XRF, in order to achieve acceptable accuracy, which requires calibration samples as fused metaborate disks using reference materials of composition, the closest possible compared to HS; this would significantly complicate the analysis.

\subsection{Water-Soluble Species of Elements in HS}

As noted above, HS samples are colloidal solutions containing highly dispersed particles of clays and other minerals. These particles can be separated in various ways; the simplest is centrifugation. However, not all the particles are deposited during centrifugation; the deposition completeness depends on the centrifugation rate, more precisely on the relative centrifuge force (RCF) and the size of the colloidal particles. As colloidal entities from several nanometers to submicron particles can be expected in HS extracts, a strict boundary between a true and colloidal solution is impossible. The centrifugation conditions selected in this study provide sedimentation-proof solutions for at least several months without forming a visible precipitate. Therefore, the name 'water-soluble' in this paper should be considered conditional. Fractionation of HS solutions by particle size followed by elemental analysis is a different challenge and is beyond the scope of this work.

The results obtained for supernatants show that the content of water-soluble forms for many elements is lower than the contents of elements in colloidal solutions. This effect is influenced by both insoluble forms of elements in HS and the cation adsorption on silicate components. As K and Na for all the samples and "Powhumus" and "Sakhalin" in solutions after centrifugation differ slightly from the results by other methods, we can conclude that these elements are almost entirely hydrated ions. In the case of K, its content in the "life force" HS sample differed before and after centrifugation and compared with the sample after ashing. Thus, some potassium is in the form of water-insoluble compounds. The behavior of lithium is entirely unexpected and is also due to colloidal particles containing lithium in bound species.

The remaining elements are present in both water-soluble and water-insoluble forms. Slight differences in the content of soluble and insoluble species of $\mathrm{Be}, \mathrm{Ca}, \mathrm{Cu}, \mathrm{Mn}, \mathrm{Ni}$, and $S$ were observed. Thus, their soluble species prevail in HS. Sulfur, most likely, is a soluble sulfates and can also be included in the soluble organic part of HS.

Thus, HS analysis with centrifugation can be expanded to use a series of solutions with increasing centrifugation times or RCFs for a deeper characterization of samples 
from this point of view. When comparing the analysis results with other methods, we can estimate the fraction of water-soluble species compared to insoluble species.

\subsection{Element Species Recovered by Boiling in Nitric Acid}

Nitric-acid extraction is one of the classical methods for analyzing trace elements in soils [44]. The boiling method with nitric acid gives the content at the level of water-soluble species or even several times lower for some elements. This result is due to a significant fraction of aluminosilicate components, which are insoluble in nitric acid and adsorb many cations. After boiling and filtering, enough sediment remains on the filter in this technique, a mixture of HA and aluminosilicate components. Only Be, Ca, K, P, Sr, and $\mathrm{Zn}$ by this technique are at the same level or higher than their contents in aqueous solutions with centrifugation. Nevertheless, boiling HS with nitric acid is not informative for estimating bulk metals; however, it can help metal speciation in HS.

In general, it can be argued that the main framework of HS is strong enough not to be oxidized under simple boiling in nitric acid, even for $3 \mathrm{~h}$. These conditions are not sufficient for mineral decomposition or the complete extraction of elements from the HS matrix.

\subsection{Element Species Recovered by Nitric Acid at $250^{\circ} \mathrm{C}$}

Microwave-assisted decomposition of HS samples with nitric acid provides the total contents of 20 elements (Table 4), including the elements that cannot be determined by borate fusion, such as $\mathrm{As}, \mathrm{B}, \mathrm{Cd}, \mathrm{Li}, \mathrm{Pb}$, and $\mathrm{S}$. Moreover, it is worth noting a significant difference between boiling in nitric acid and microwave-assisted decomposition with nitric acid for lithium and boron. Moreover, $\mathrm{B}, \mathrm{Cd}, \mathrm{Li}, \mathrm{Pb}$, and $\mathrm{S}$ can be reliably determined only after microwave-assisted decomposition with nitric acid.

Table 4. Optimum methods for the assessment of the bulk contents of elements in humate samples (n.d. means that the element is not determined by this method; + , this technique can be used; $x$, lack of sensitivity or chemical properties do not provide the determination; blank, incompleteextraction of an element by this method).

\begin{tabular}{|c|c|c|c|c|c|}
\hline & $\begin{array}{l}\text { Water Extract } \\
\text { w/Centr. }\end{array}$ & $\begin{array}{l}\text { Water Extract } \\
\text { Wo/Centr. }\end{array}$ & $\begin{array}{l}\text { Nitric Acid } \\
\text { Boiling }\end{array}$ & $\begin{array}{l}\text { MW-Assisted } \\
\text { Nitric Acid }\end{array}$ & $\begin{array}{l}\text { Metaborate } \\
\text { Fusion }\end{array}$ \\
\hline $\mathrm{Ag}$ & n.d. & n.d. & n.d. & n.d. & n.d. \\
\hline $\mathrm{Al}$ & & + & & + & + \\
\hline As & & + & & + & $x$ \\
\hline B & & + & & + & $x$ \\
\hline Ba & & & & + & + \\
\hline Be & & + & & + & \\
\hline $\mathrm{Ca}$ & + & + & + & + & + \\
\hline $\mathrm{Cd}$ & & & & + & $x$ \\
\hline Co & & + & & + & \\
\hline $\mathrm{Cr}$ & & + & & + & + \\
\hline $\mathrm{Cu}$ & + & + & & + & \\
\hline $\mathrm{Fe}$ & & + & & + & + \\
\hline K & + & + & + & + & \\
\hline $\mathrm{Li}$ & & + & & + & $x$ \\
\hline $\mathrm{Mg}$ & & + & & + & + \\
\hline $\mathrm{Mn}$ & & + & & + & + \\
\hline Mo & & + & & & $x$ \\
\hline $\mathrm{Na}$ & & & & + & + \\
\hline $\mathrm{Ni}$ & & + & & + & + \\
\hline $\mathrm{P}$ & & & & & + \\
\hline $\mathrm{Pb}$ & & & & + & \\
\hline S & & & & + & $x$ \\
\hline $\mathrm{Sb}$ & n.d. & n.d. & n.d. & n.d. & n.d. \\
\hline
\end{tabular}


Table 4. Cont.

\begin{tabular}{cccccc}
\hline & $\begin{array}{c}\text { Water Extract } \\
\text { w/Centr. }\end{array}$ & $\begin{array}{c}\text { Water Extract } \\
\text { Wo/Centr. }\end{array}$ & $\begin{array}{c}\text { Nitric Acid } \\
\text { Boiling }\end{array}$ & $\begin{array}{c}\text { MW-Assisted } \\
\text { Nitric Acid }\end{array}$ & $\begin{array}{c}\text { Metaborate } \\
\text { Fusion }\end{array}$ \\
\hline Se & n.d. & n.d. & n.d. & n.d. & n.d. \\
Si & & & & & + \\
Sn & & & & + & + \\
Sr & & & & & + \\
$\mathrm{Ti}$ & & & & & + \\
$\mathrm{V}$ & & & & \\
$\mathrm{W}$ & & & & + \\
$\mathrm{Zn}$ & & & & & + \\
\hline
\end{tabular}

However, Ti is markedly underestimated for microwave-assisted decomposition than other methods; titanium compounds are insoluble in nitric acid without hydrofluoric acid. This effect is even more pronounced for silicon compounds.

Acid-soluble species mainly represent magnesium in HS samples; moreover, in solutions after microwave-assisted decomposition, its content is higher than in colloidal solutions, which may be associated with the sedimentation of Mg-containing large particles. Thus, the assisted decomposition completely decomposes the sample and eliminates the wrong results from particle sedimentation. The content of $\mathrm{Cu}$ and $\mathrm{Sn}$ in the solutions after acid decomposition is underestimated compared to fusion. Most likely, these metals are present in the sample, including oxide species that are poorly soluble in nitric acid (approximately $30-40 \% w / w$ ). Thus, microwave-assisted decomposition using nitric acid provides reliable determination of trace elements, especially those that are hazardous, and the total lithium and boron.

\subsection{Comparison of Sample Preparation Methods and Elemental Composition of HS Samples}

For most metals ( $\mathrm{Al}, \mathrm{Ba}, \mathrm{Co}, \mathrm{Cu}, \mathrm{Fe}, \mathrm{Mg}, \mathrm{Mn}, \mathrm{Ni}, \mathrm{Sn}, \mathrm{Ti}, \mathrm{V}$, and $\mathrm{W})$, there is an increase in the element content in the row "water extract with centrifugation-without centrifugationmicrowave-assisted decomposition with nitric acid-fusion with lithium metaborate". The same dependence is observed for $\mathrm{Ca}, \mathrm{K}, \mathrm{P}, \mathrm{Sr}$, and $\mathrm{Zn}$, but not for all preparations, which may be due to the sample heterogeneity. The fusion technique provides the bulk content of all these 17 elements (Table 4).

Summarizing the studies on elemental analysis of $\mathrm{HS}$ gives the following set of elements: $\mathrm{Al}, \mathrm{As}, \mathrm{B}, \mathrm{Ba}, \mathrm{Ca}, \mathrm{Cd}, \mathrm{Co}, \mathrm{Cr}, \mathrm{Cu}, \mathrm{Fe}, \mathrm{K}, \mathrm{Mg}$, Mo, Mn, $\mathrm{Na}, \mathrm{Ni}, \mathrm{P}, \mathrm{Pb}, \mathrm{Ti}, \mathrm{S}, \mathrm{Se}$, $\mathrm{Sr}, \mathrm{V}, \mathrm{Zn}$, and Zr. In this study, we expanded the set to 31 elements. Table 5 includes the analysis of HS samples from various sources, geographic locations, depths, and element isolation and quantification by various methods. We selected the minimum and maximum concentrations of each element to assess whether the element is usually present in HS.

The contents of elements in HS varies greatly depending on these parameters. Nevertheless, a general trend can be traced, confirmed by our results. The main components of the mineral part are $\mathrm{Al}, \mathrm{Fe}, \mathrm{S}$, and $\mathrm{Si}$. $\mathrm{K}$ and $\mathrm{Na}$ act as counterions for our $\mathrm{HS}$. $\mathrm{Ca}, \mathrm{Mg}$, $\mathrm{P}, \mathrm{Ti}$, and $\mathrm{Zn}$ are found in high concentrations. In the minor amounts (less than $0.01 \%$ ), $\mathrm{Be}, \mathrm{Cd}, \mathrm{Co}, \mathrm{Mo}, \mathrm{Pb}$, and $\mathrm{Sn}$ are found in all three preparations (Supplementary Materials, Figures $\mathrm{S6}-\mathrm{S} 8$ ). Although the contents of $\mathrm{Al}, \mathrm{Ba}, \mathrm{Fe}, \mathrm{Mn}$, and $\mathrm{Sr}$ in aqueous solutions without centrifugation and by microwave-assisted decomposition differ from the results by fusion by no more than $15 \%$, the fusion provides higher concentrations of extracted elements compared to acid digestion. Thus, these elements are present as tiny particles that do not settle during centrifugation and large particles chemically bound to silicates. 
Table 5. Element composition of humic substances as $c_{1} / c_{2}$, where $c_{1}$ is the minimum found concentration $\left(\mathrm{mg} \mathrm{kg}^{-1}\right)$ and $c_{2}$ is the maximum found concentration $\left(\mathrm{mg} \mathrm{kg}^{-1}\right) ; \mathrm{n} / \mathrm{d}$ is not determined or below LOD.

\begin{tabular}{|c|c|c|c|c|c|c|c|c|c|}
\hline \multicolumn{10}{|c|}{ Amount, mg kg-1 } \\
\hline Material & $\begin{array}{c}\text { Soil FA } \\
\text { [23] }\end{array}$ & $\begin{array}{c}\text { HS from } \\
\text { Sediments } \\
{[24]}\end{array}$ & $\begin{array}{c}\text { HS from } \\
\text { Sediments } \\
{[25]}\end{array}$ & $\begin{array}{c}\text { HS from } \\
\text { Sediments } \\
{[26]}\end{array}$ & $\begin{array}{c}\text { Humin from } \\
\text { a Buried } \\
\text { Volcanic Ash } \\
\text { Soil Profile } \\
\text { and a Peat } \\
\text { Soil [27] }\end{array}$ & $\begin{array}{l}\text { Aquatic } \\
\text { HS [29] }\end{array}$ & $\begin{array}{c}\text { HA from } \\
\text { Soil [31] }\end{array}$ & $\begin{array}{c}\text { HS from } \\
\text { Sediments } \\
{[32]}\end{array}$ & $\begin{array}{c}\text { This Study } \\
\text { (the Maximum } \\
\text { Conc. among } \\
\text { Selected } \\
\text { Approaches) }\end{array}$ \\
\hline $\mathrm{Al}$ & & n.d./3100 & $60 / 656$ & & $3000 / 6890$ & & 552 & $322 / 668$ & $9600 / 33,000$ \\
\hline As & & & & & $200 / 400$ & & & & $1.3 / 27$ \\
\hline B & & & n.d./17 & & & & & & $9 / 13$ \\
\hline $\mathrm{Ba}$ & & & $2 / 29$ & & & & & & $88 / 410$ \\
\hline $\mathrm{Be}$ & & & & & & & & & $0.7 / 4$ \\
\hline $\mathrm{Ca}$ & $2.9 / 5.6$ & & n.d./84 & & n.d. $/ 24,600$ & & 560 & & $5500 / 10,200$ \\
\hline $\mathrm{Cd}$ & & $0.3 / 2.9$ & & $0.5 / 1.3$ & & $4.7 / 1290$ & & $\begin{array}{l}3 \times 10^{-5} / \\
8 \times 10^{-5}\end{array}$ & $0.4 / 0.8$ \\
\hline Co & & & n.d./19 & $8 / 33$ & & & n.d. & $0.02 / 0.04$ & $6 / 16$ \\
\hline $\mathrm{Cr}$ & & & n.d./59 & $10 / 31$ & & & 22 & $0.3 / 0.9$ & $7 / 44$ \\
\hline $\mathrm{Cu}$ & & $118 / 433$ & $126 / 1264$ & $900 / 1706$ & n.d./800 & $17.2 / 224$ & 304 & $0.5 / 1.06$ & $5 / 33$ \\
\hline $\mathrm{Fe}$ & n.d. $/ 0.720$ & & $26 / 786$ & $9270 / 17,720$ & $200 / 41,900$ & $345 / 29,020$ & 2800 & $200 / 428$ & $3200 / 33,000$ \\
\hline $\mathrm{K}$ & $4.9 / 8.8$ & & & & $60 / 470$ & & & & $1700 / 83,000$ \\
\hline $\mathrm{Li}$ & & & & & & & & & $3 / 32$ \\
\hline $\mathrm{Mg}$ & & & n.d./57 & & $100 / 29,600$ & & & & $1000 / 2200$ \\
\hline $\mathrm{Mn}$ & & & n.d./60 & n.d./136 & n.d./3200 & 4/1094 & 225 & $0.07 / 0.15$ & $16 / 66$ \\
\hline Mo & & & $109 / 981$ & & & & & & $0.8 / 10$ \\
\hline $\mathrm{Na}$ & $4.6 / 14$ & & & & & & & & $1469 / 72,000$ \\
\hline $\mathrm{Ni}$ & & & $1 / 87$ & n.d. $/ 240$ & & $6 / 178$ & n.d. & $1.4 / 3.2$ & $27 / 59$ \\
\hline $\mathrm{P}$ & & & $694 / 2727$ & & $480 / 1890$ & & & & $48 / 2400$ \\
\hline $\mathrm{Pb}$ & & $3.9 / 28.1$ & n.d./12 & n.d./102 & & $17 / 360$ & n.d. & $0.8 / 2.0$ & $3 / 7$ \\
\hline$S$ & & & & & $600 / 3300$ & & & & $1500 / 3000$ \\
\hline $\mathrm{Si}$ & & & & & $3300 / 6700$ & & & & $14,200 / 34,900$ \\
\hline $\mathrm{Sn}$ & & & & & & & & & $9 / 27$ \\
\hline $\mathrm{Sr}$ & & & & & & & 5.2 & & $44 / 770$ \\
\hline $\mathrm{Ti}$ & & & $11 / 98$ & & n.d. $/ 40,200$ & & & & $360 / 2500$ \\
\hline $\mathrm{V}$ & & & n.d./11 & & $700 / 7900$ & & n.d. & & $10 / 77$ \\
\hline W & & & & & & & & & $24 / 33$ \\
\hline $\mathrm{Zn}$ & $0.01 / 0.05$ & $56 / 363$ & $11 / 462$ & $39 / 146$ & & $32 / 1479$ & 67 & $1 / 2.4$ & $16 / 30$ \\
\hline
\end{tabular}

It is essential to understand that the determination results depend on the method sensitivity since, in some studies, it was possible to determine an element using only one of the two methods. The last column of Table 5 shows the bulk element contents in this study. For this, the highest concentrations were selected among all the methods. It shows that all three HS samples have the same qualitative elemental composition; however, the amount of some elements differs from the average: "Powhumus" has a higher content of As, Cr, Li, and V; "Sakhalin", Ba, Co, Cr, Fe, Ni, P, and Sr; and "Life Force", Mo. The bulk concentration (the highest among all decomposition methods) was selected for each element and recalculated to oxide to calculate the mineral composition. The highest content of mineral components was found in "Powhumus" and "Sakhalin" samples (336 and $323 \mathrm{~g} \mathrm{~kg}^{-1}$, respectively). "Life Force" shows $220 \mathrm{~g} \mathrm{~kg}^{-1}$ of mineral components. The percentage distribution of metals is shown in Figures S6-S8 (Supplementary Materials). Summarized data on the best methods for determining the gross content of elements in humate samples are in Table 4. As $\mathrm{K}$ and $\mathrm{Na}$ in some HS samples are main counterions for $\mathrm{COO}^{-}$groups, while they can be minor components in others, their examples show the relationship between the sample weight and the analysis result. Depending on the samplepreparation method (and, hence, the concentration level of element), their concentration ratios by selected methods differ.

The selected methods give different results on the content of elements due to their chemical properties; it is also worth considering the limits of detection of elements by these methods, which depend on the sample weights at the decomposition stage (Table 6). To calculate the 'default', characteristic, limits of detection, and quantification of metals in HS, we took the Russian national environmental regulatory document on the quantitative chemical analysis of water using ICP-AES as a basis. The selected sample-preparation procedures make it possible to reach the expected quantification limits for most test elements, especially 
for main hazardous elements (As, $\mathrm{Cd}, \mathrm{Pb}$, and $\mathrm{Ni}$ ). However, sample decomposition for $\mathrm{Ag}$, $\mathrm{Sb}$, and $\mathrm{Se}$ and subsequent ICP-AES analysis does not give a positive result.

Table 6. Limits of quantification ( $\mathrm{mg} \mathrm{kg}^{-1}$ of elements in generic aqueous solutions and found for the selected approaches to sample decomposition of humic substances).

\begin{tabular}{|c|c|c|c|c|c|}
\hline Procedure & $\begin{array}{c}\text { ICP-AES in } \\
\text { Aqueous Samples } 1\end{array}$ & $\begin{array}{l}\text { Direct Analysis of } \\
\text { Aqueous Extracts }\end{array}$ & $\begin{array}{l}\text { Nitric Acid } \\
\text { Boiling }\end{array}$ & $\begin{array}{l}\text { MW-Assisted } \\
\text { Nitric-Acid }\end{array}$ & $\begin{array}{c}\text { Metaborate } \\
\text { Fusion }\end{array}$ \\
\hline Element & $\mathrm{mg} \mathrm{L}^{-1}$ & \multicolumn{4}{|c|}{$\mathrm{mg} \mathrm{kg}^{-1}$} \\
\hline $\mathrm{Ag}$ & 0.005 & 0.25 & 0.125 & 0.625 & 0.625 \\
\hline $\mathrm{Al}$ & 0.01 & 0.5 & 0.25 & 1.25 & 1.25 \\
\hline As & 0.005 & 0.25 & 0.125 & 0.625 & 0.625 \\
\hline B & 0.01 & 0.5 & 0.25 & 1.25 & 1.25 \\
\hline $\mathrm{Ba}$ & 0.001 & 0.05 & 0.025 & 0.125 & 0.125 \\
\hline $\mathrm{Be}$ & 0.0001 & 0.005 & 0.0025 & 0.0125 & 0.0125 \\
\hline $\mathrm{Ca}$ & 0.01 & 0.5 & 0.25 & 1.25 & 1.25 \\
\hline $\mathrm{Cd}$ & 0.0001 & 0.005 & 0.0025 & 0.0125 & 0.0125 \\
\hline Co & 0.001 & 0.05 & 0.025 & 0.125 & 0.125 \\
\hline $\mathrm{Cr}$ & 0.001 & 0.05 & 0.025 & 0.125 & 0.125 \\
\hline $\mathrm{Cu}$ & 0.001 & 0.05 & 0.025 & 0.125 & 0.125 \\
\hline $\mathrm{Fe}$ & 0.05 & 2.5 & 1.25 & 6.25 & 6.25 \\
\hline $\mathrm{K}$ & 0.05 & 2.5 & 1.25 & 6.25 & 6.25 \\
\hline $\mathrm{Li}$ & 0.01 & 0.5 & 0.25 & 1.25 & 1.25 \\
\hline $\mathrm{Mg}$ & 0.05 & 2.5 & 1.25 & 6.25 & 6.25 \\
\hline $\mathrm{Mn}$ & 0.001 & 0.05 & 0.025 & 0.125 & 0.125 \\
\hline Mo & 0.001 & 0.05 & 0.025 & 0.125 & 0.125 \\
\hline $\mathrm{Na}$ & 0.5 & 25 & 12.5 & 62.5 & 62.5 \\
\hline $\mathrm{Ni}$ & 0.001 & 0.05 & 0.025 & 0.125 & 0.125 \\
\hline $\mathrm{P}$ & 0.02 & 1 & 0.5 & 2.5 & 2.5 \\
\hline $\mathrm{Pb}$ & 0.001 & 0.05 & 0.025 & 0.125 & 0.125 \\
\hline$S$ & 0.05 & 2.5 & 1.25 & 6.25 & 6.25 \\
\hline $\mathrm{Sb}$ & 0.005 & 0.25 & 0.125 & 0.625 & 0.625 \\
\hline Se & 0.005 & 0.25 & 0.125 & 0.625 & 0.625 \\
\hline $\mathrm{Si}$ & 0.05 & 2.5 & 1.25 & 6.25 & 6.25 \\
\hline Sn & 0.005 & 0.25 & 0.125 & 0.625 & 0.625 \\
\hline $\mathrm{Sr}$ & 0.001 & 0.05 & 0.025 & 0.125 & 0.125 \\
\hline $\mathrm{Ti}$ & 0.001 & 0.05 & 0.025 & 0.125 & 0.125 \\
\hline $\mathrm{V}$ & 0.001 & 0.05 & 0.025 & 0.125 & 0.125 \\
\hline W & 0.01 & 0.5 & 0.25 & 1.25 & 1.25 \\
\hline $\mathrm{Zn}$ & 0.005 & 0.25 & 0.125 & 0.625 & 0.625 \\
\hline
\end{tabular}

${ }^{1}$ by PND F 14.1: 2: 4.135-98 Russian national environmental regulatory document.

Table 7 presents the limits of detection of elements for aqueous solutions and the content of these elements in the analyzed samples, which lie below the corresponding characteristic LODs. This problem can be overcome by increasing the sample weight by order of magnitude. However, it is technically challenging (an increase in the size of crucibles for fusion or test tubes for microwave decomposition); extracts with nitric acid require the same sample ratio as the extractant solution. Thus, to significantly reduce the limits of determination, ICP-MS should be used. However, in our opinion, for most HS applications, the sensitivity of ICP-AES is sufficient, which is confirmed by reaching the maximum allowable concentration levels and is discussed in detail in the section below. 
Table 7. Limits of detection of elements and contents of elements in the analyzed humic-substance samples below LOD values.

\begin{tabular}{|c|c|c|c|c|c|c|}
\hline \multirow{2}{*}{ Element } & \multirow[t]{2}{*}{ Wavelength, nm } & \multirow{2}{*}{$\mathrm{LOD}, \mu \mathrm{g} \mathrm{\textrm {L } ^ { - 1 } *}$} & $\begin{array}{c}\text { Water } \\
\text { Extract/Wo Centr. }\end{array}$ & $\begin{array}{l}\text { Nitric-Acid } \\
\text { Boiling }\end{array}$ & $\begin{array}{l}\text { MW-Assisted } \\
\text { Nitric Acid }\end{array}$ & $\begin{array}{c}\text { Metaborate } \\
\text { Fusion }\end{array}$ \\
\hline & & & \multicolumn{4}{|c|}{ LOD, mg kg ${ }^{-1}$} \\
\hline $\mathrm{Ag}$ & 328.068 & 0.3 & 0.015 & 0.008 & 0.038 & 0.038 \\
\hline $\mathrm{Al}$ & 396.153 & 1.1 & 0.055 & 0.028 & 0.138 & 0.138 \\
\hline As & 193.759 & 4.9 & 0.245 & 0.123 & 0.613 & 0.613 \\
\hline $\mathrm{B}$ & 208.956 & 2.1 & 0.105 & 0.053 & 0.263 & 0.263 \\
\hline $\mathrm{Ba}$ & 455.403 & 0.03 & 0.002 & 0.001 & 0.004 & 0.004 \\
\hline $\mathrm{Be}$ & 313.042 & 0.06 & 0.003 & 0.002 & 0.008 & 0.008 \\
\hline $\mathrm{Ca}$ & 393.366 & 0.07 & 0.004 & 0.002 & 0.009 & 0.009 \\
\hline $\mathrm{Cd}$ & 228.802 & 0.09 & 0.005 & 0.002 & 0.011 & 0.011 \\
\hline Co & 230.786 & 0.2 & 0.010 & 0.005 & 0.025 & 0.025 \\
\hline $\mathrm{Cr}$ & 267.716 & 0.8 & 0.040 & 0.020 & 0.100 & 0.100 \\
\hline $\mathrm{Cu}$ & 327.395 & 0.5 & 0.025 & 0.013 & 0.063 & 0.063 \\
\hline $\mathrm{Fe}$ & 238.204 & 0.4 & 0.020 & 0.010 & 0.050 & 0.050 \\
\hline $\mathrm{K}$ & 766.491 & 20 & 1.000 & 0.500 & 2.500 & 2.500 \\
\hline $\mathrm{Li}$ & 670.784 & 0.3 & 0.015 & 0.008 & 0.038 & 0.038 \\
\hline $\mathrm{Mg}$ & 279.553 & 0.5 & 0.025 & 0.013 & 0.063 & 0.063 \\
\hline $\mathrm{Mn}$ & 257.61 & 0.4 & 0.020 & 0.010 & 0.050 & 0.050 \\
\hline Mo & 202.032 & 0.6 & 0.030 & 0.015 & 0.075 & 0.075 \\
\hline $\mathrm{Na}$ & 589.592 & 10 & 0.500 & 0.250 & 1.250 & 1.250 \\
\hline $\mathrm{Ni}$ & 221.648 & 0.2 & 0.010 & 0.005 & 0.025 & 0.025 \\
\hline $\mathrm{P}$ & 214.914 & 7.2 & 0.360 & 0.180 & 0.900 & 0.900 \\
\hline $\mathrm{Pb}$ & 220.353 & 0.9 & 0.045 & 0.023 & 0.113 & 0.113 \\
\hline$S$ & 180.669 & 5 & 0.250 & 0.125 & 0.625 & 0.625 \\
\hline $\mathrm{Sb}$ & 206.833 & 1.4 & 0.070 & 0.035 & 0.175 & 0.175 \\
\hline Se & 196.09 & 2.2 & 0.110 & 0.055 & 0.275 & 0.275 \\
\hline $\mathrm{Si}$ & 251.611 & 3.1 & 0.155 & 0.078 & 0.388 & 0.388 \\
\hline Sn & 189.989 & 2.8 & 0.140 & 0.070 & 0.350 & 0.350 \\
\hline $\mathrm{Sr}$ & 407.771 & 0.1 & 0.005 & 0.003 & 0.013 & 0.013 \\
\hline $\mathrm{Ti}$ & 334.941 & 0.3 & 0.015 & 0.008 & 0.038 & 0.038 \\
\hline $\mathrm{V}$ & 292.401 & 0.9 & 0.045 & 0.023 & 0.113 & 0.113 \\
\hline W & 207.911 & 5.3 & 0.265 & 0.133 & 0.663 & 0.663 \\
\hline $\mathrm{Zn}$ & 213.856 & 0.06 & 0.003 & 0.002 & 0.008 & 0.008 \\
\hline
\end{tabular}

* by PND F 14.1: 2: 4.135-98 Russian national environmental regulatory document.

Thus, a single decomposition technique is insufficient for the simultaneous quantitative determination of all HS elements. Microwave decomposition and/or metaborate fusion make the most detailed determination (bulk) of metal contents possible. Figure 1 shows the correlation of the content of elements by direct determination of colloidal solutions and ashing/fusion for different samples. It shows that the analysis of water extracts is sufficient for determining As, B, Be, Ca, Co, Mo, and Zn. Moreover, microwave-assisted decomposition with nitric acid and fusion for Mo gives unsatisfactory results. This behavior explains (see Table 4) why, despite the different nature of the samples, we obtained higher contents of some elements in HS than the published data; not all the techniques used in previous studies simultaneously extract all the elements completely. 


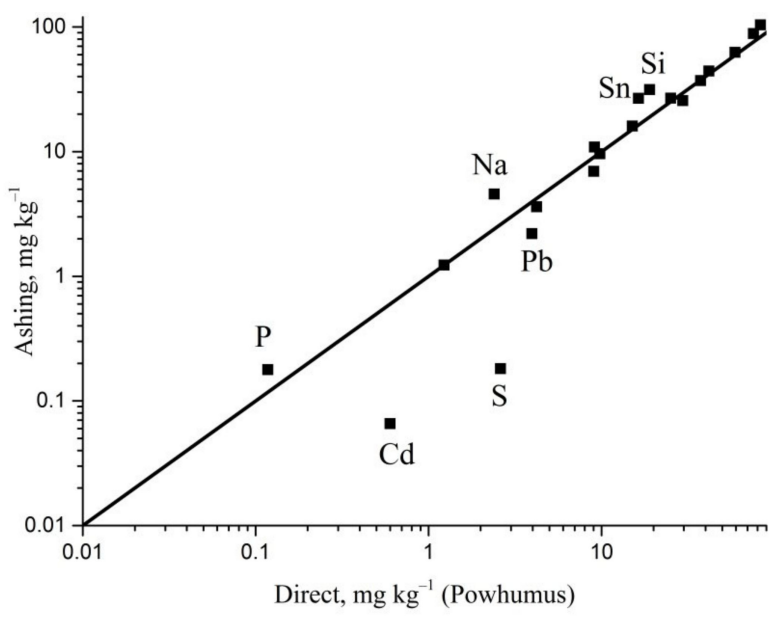

(a)

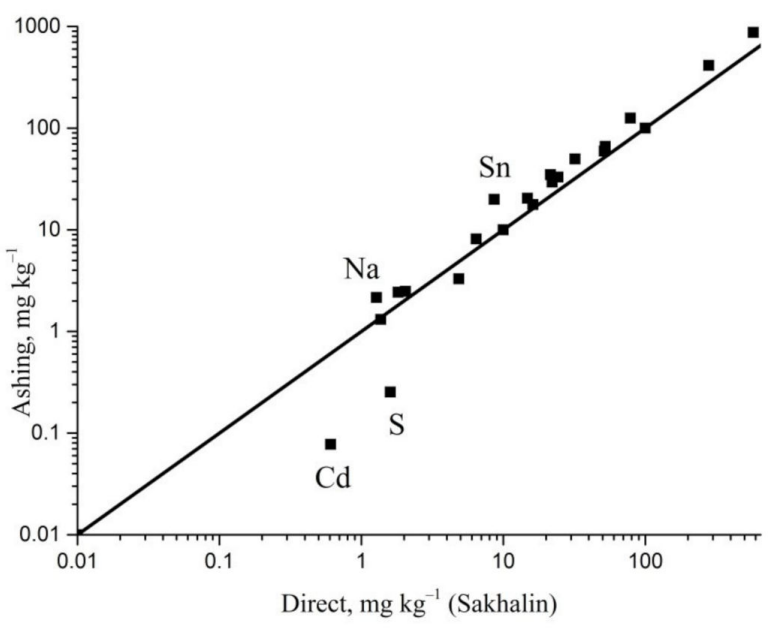

(b)

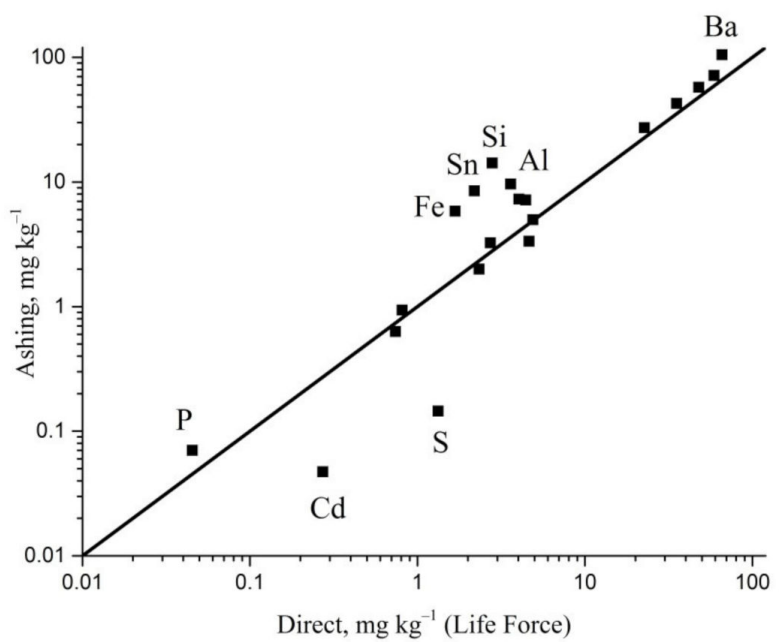

(c)

Figure 1. Correlation of the results of the determination of the content of elements by direct determination of colloidal solutions (abscissa) and ashing followed by metaborate fusion (ordinate) for "Powhumus" (a), "Sakhalin" (b), and “Life Force" (c) humic-substance samples. 


\subsection{Mineral Composition of HS as Components of Dietary Supplements and Drugs}

HS-based dietary supplements belong to the category of drugs, for which the raw materials are natural components that have not yet been studied in detail and may be hazardous [7]. Therefore, it is necessary to solve the following problems: (i) the concentration of HS themselves in industrial preparations, as well as (ii) the assessment of purity of supplements and the correspondence to HS.

Topical is the development of various methods that provide the most comprehensive characterization of HS to introduce uniform criteria for controlling the production and use of HS. Previously, we proposed a method for the direct quantitative determination of HS in fertilizers, which revealed a significant fraction of aluminosilicate components of HS [39]. In this study, we compared various sample-preparation techniques for microelement HS analysis, and the tests can be considered practical applications of the proposed approaches.

Dietary supplements are not medicines. Therefore, they have underestimated requirements when registering drugs and controlling their quality and production, and the assessment of the biological effect, as mentioned above, is not sometimes tested on humans. In the EU and the USA, food additives are equated with food rather than medicines. Nutritional supplements are not covered by the safety and efficacy testing requirements for medicines, and unlike medicines, they do not require prior approval by the relevant organizations (such as the FDA in the United States). Under the 1994 US law (The Dietary Supplement Health and Education Act), manufacturers must notify about new drugs, but not about the ingredients in their composition. According to the EU Food Additives Directive of 2002, they must be safe in dosage and purity. Only the supplements proven safe can be sold over the counter in the EU. As a food category, nutritional supplements cannot be labeled as drugs but may contain claims of nutrients or health hazards. However, certain aspects of legislation remain in the national regulation of EU member states. EU countries cannot agree on a common approach in using ingredients of plant origin and other minor components of food in dietary supplements.

Strict regulation of raw material quality and safety is required to let HS-based dietary supplements enter the market. However, the sources of HS often contain hazardous elements: arsenic is often found in humates of coal origin, which is contained in the feedstock $[45,46]$ and shilajit (mumijo), a widespread HS-related supplement used for more than 3000 years, contains more than 50 elements, among which are some hazardous elements [47]. Cadmium is toxic to the kidneys. Lead causes impaired neurological development in kidneys and reproductive system functioning. It can also cause mortality due to cardiovascular diseases. Moreover, according to the FDA, the most hazardous are inorganic compounds of arsenic compared with arsenic associated with organic carbon. Nickel compounds are also carcinogenic to humans and can cause allergic dermatitis. The primary source of mercury is seafood; therefore, mercury analysis in this work was considered. The maximum allowable concentrations of elements for oral administration are shown in Table 8. None of the determined elements, except for arsenic, exceeds the maximum allowable concentration.

Other elements are necessary for the functioning of the body. Several elements (Co, $\mathrm{Cr}, \mathrm{Cu}, \mathrm{Fe}, \mathrm{Mo}, \mathrm{Mn}, \mathrm{Se}$, and $\mathrm{Zn}$ ) are used in replenishing nutraceutical deficiencies. Thus, it is crucial to know the dosage of the element in dietary supplements that have the proper therapeutic effect and have no side effects if the dosage is exceeded [49]. Since HS contains such a rich mineral composition, it can be both a source of micronutrients for plants and animals and a source of hazardous elements, polluting soils and poisoning organisms of plants and animals [50-53]. 
Table 8. Maximum allowable concentrations for daily intake of elements and dietary reference consumption (males, 31-50 years old); Dietary Reference Intakes (DRIs).

\begin{tabular}{|c|c|c|c|c|c|c|}
\hline \multirow[b]{2}{*}{ Element } & \multicolumn{2}{|c|}{$\begin{array}{l}\text { Minimal Risk Levels (MRLs) for } \\
\text { Hazardous Substances, Oral }\end{array}$} & \multicolumn{2}{|c|}{$\begin{array}{l}\text { Dietary Reference } \\
\text { Intakes (DRIs) [48] }\end{array}$} & \multirow[b]{2}{*}{$\begin{array}{c}\text { The Maximum } \\
\text { Amount Found } \\
\text { in } \mathrm{HS}_{\text {, }} \\
\mathrm{mg} \mathrm{kg}^{-1} *\end{array}$} & \multirow{2}{*}{$\begin{array}{c}\text { Daily Intake } \\
\text { with the } \\
\text { Supplement } \\
\text { (600 mg HS), } \\
\text { mg ** }\end{array}$} \\
\hline & mg kg ${ }^{-1}$ day $^{-1}$ & $\begin{array}{l}\text { Recalc. to a } \\
70-k g \text { Male }\end{array}$ & $\begin{array}{c}\text { Recommended } \\
\text { Dietary } \\
\text { Allowances and } \\
\text { Adequate Intakes, } \\
\text { mg day }^{-1}\end{array}$ & $\begin{array}{c}\text { Tolerable } \\
\text { Upper Intake } \\
\text { Levels, } \\
\text { mg day }^{-1}\end{array}$ & & \\
\hline $\mathrm{Al}$ & 1 & 70 & & & 33 & 0.02 \\
\hline As & $\begin{array}{c}3 \times 10^{-4} / \\
5 \times 10^{-3 * * *}\end{array}$ & 0.4 & & & 27 & 0.02 \\
\hline $\mathrm{B}$ & 0.2 & 14 & & & 13 & 0.01 \\
\hline $\mathrm{Ba}$ & 0.2 (soluble) & 14 & & & 410 & 0.3 \\
\hline $\mathrm{Be}$ & 0.02 & 1.4 & & & 4.2 & $3 \times 10^{-3}$ \\
\hline $\mathrm{Ca}$ & & & 1000 & 2500 & 10,200 & 6 \\
\hline $\mathrm{Cd}$ & $10^{-4} / 5 \times 10^{-4 * * *}$ & 0.04 & & & 0.8 & $5 \times 10^{-4}$ \\
\hline $\mathrm{Co}$ & 0.01 & 0.7 & & & 18 & 0.01 \\
\hline $\mathrm{Cr}$ & $\begin{array}{c}9 \times 10^{-4} / \\
5 \times 10^{-3 * * *}\end{array}$ & 0.4 & & & 0.7 & $4 \times 10^{-4}$ \\
\hline $\mathrm{Cu}$ & 0.01 & 0.7 & & & 32 & 0.02 \\
\hline $\mathrm{Fe}$ & & & 8 & 45 & 20,400 & 12 \\
\hline $\mathrm{K}$ & & & 3400 & n.d. & 83,000 & 50.0 \\
\hline $\mathrm{Mg}$ & & & 420 & 350 & 2500 & 1.5 \\
\hline Mn & & & 2.3 & 11 & 62 & 0.04 \\
\hline Mo & $8 \times 10^{-3} / 0.05^{* * *}$ & 3.5 & & & 10 & 0.01 \\
\hline $\mathrm{Na}$ & & & 1500 & n.d. & 72,000 & 43 \\
\hline $\mathrm{Ni}$ & & & - & 1 & 60 & 0.04 \\
\hline $\mathrm{P}$ & & & 700 & 4000 & 2400 & 1.5 \\
\hline $\mathrm{Sb}$ & $6 \times 10^{-4} / 1^{* * *}$ & 70 & & & n.d. & n.d. \\
\hline Se & $5 \cdot 10^{-3}$ & 0.4 & & & n.d. & n.d. \\
\hline $\mathrm{Si}$ & & & - & n.d. & 35,000 & 21 \\
\hline Sn & 0.3 & 21 & & & 27 & 0.02 \\
\hline $\operatorname{Sr}(2+)$ & 2 & 140 & & & 870 & 0.5 \\
\hline $\mathrm{V}$ & 0.01 & 0.7 & & & 77 & 0.05 \\
\hline $\mathrm{Zn}(2+)$ & 0.3 & 21 & & & 41 & 0.02 \\
\hline
\end{tabular}

* the maximum content of the element among all samples and decomposition approaches. ${ }^{* *}$ average doses per day when taking dietary supplements. ${ }^{* * *}$ depending on the duration of admission.

Thus, the analysis of the mineral composition of HS and especially trace elements, among which are highly hazardous to humans, is of great importance not only for research in environmental issues but also for HS-based products in other fields. This study shows that the initial HS contain a large and diverse set of trace elements, and manufacturers of HSbased supplements often underestimate this feature. Our proposed elemental composition control techniques will help fill this gap, which may be a subject of a separate paper.

\subsection{Reference Materials}

The content of the elements in the reference materials was determined to estimate the accuracy. For this task, two reference materials of water (surface and waste) and three reference soil standards (two national reference standards and one inter-laboratory comparative sample (ILCS)) were used. The certified values for the soil standard were only known for the extract obtained by boiling in $5 \mathrm{M}$ nitric acid. $\mathrm{HNO}_{3}$. The results are in Tables 9 and 10. 
Table 9. Content of elements in surface and wastewater reference materials by ICP-OES.

\begin{tabular}{|c|c|c|c|c|c|c|c|c|c|c|c|c|}
\hline \multirow{3}{*}{$\begin{array}{c}\text { Element } \\
\mathrm{Al}\end{array}$} & \multicolumn{6}{|c|}{ Surface Water } & \multicolumn{6}{|c|}{ Wastewater } \\
\hline & \multicolumn{3}{|c|}{ Certified Value, $\mu \mathrm{g} \mathrm{L}^{-1}$} & \multicolumn{3}{|c|}{ Measured Value, $\mu \mathrm{g} \mathrm{L}^{-1}$} & \multicolumn{3}{|c|}{ Certified Value, $\mu \mathrm{g} \mathrm{L}^{-1}$} & \multicolumn{3}{|c|}{ Measured Value, $\mu \mathrm{g} \mathrm{L}^{-1}$} \\
\hline & 250 & \pm & 1 & 268 & \pm & 64 & 2000 & \pm & 10 & 2328 & \pm & 372 \\
\hline As & 50.0 & \pm & 0.3 & 60.7 & \pm & 19.4 & 100.0 & \pm & 0.5 & 116 & \pm & 37 \\
\hline $\mathrm{B}$ & 250 & \pm & & 219 & \pm & 53 & - & & & & & \\
\hline $\mathrm{Ca}$ & 10,000 & \pm & 50 & 10,550 & \pm & 2530 & - & & & & & \\
\hline $\mathrm{Cd}$ & - & & & - & & & 20.0 & \pm & 0.1 & 23.9 & \pm & 7.7 \\
\hline Co & 10.00 & \pm & 0.05 & 9.7 & \pm & 2.5 & 60.0 & \pm & 0.3 & 59.3 & \pm & 11.9 \\
\hline $\mathrm{Cr}$ & 10.00 & \pm & 0.05 & 9.5 & \pm & 2.5 & 200 & \pm & 1 & 198 & \pm & 40 \\
\hline $\mathrm{Cu}$ & 100 & \pm & 1 & 81 & \pm & 21 & 400 & \pm & 2 & 344 & \pm & 90 \\
\hline $\mathrm{Fe}$ & 100 & \pm & 1 & 96 & \pm & 23 & 1000 & \pm & 5 & 926 & \pm & 139 \\
\hline $\mathrm{K}$ & 1000 & \pm & 5 & 1258 & \pm & 302 & - & & & & & \\
\hline $\mathrm{Mg}$ & 2000 & \pm & 10 & 1958 & \pm & 470 & - & & & & & \\
\hline $\mathrm{Mn}$ & 50.0 & \pm & 0.3 & 44.5 & \pm & 14.2 & 400 & \pm & 2 & 389 & \pm & 93 \\
\hline Mo & 50.0 & \pm & 0.3 & 43.3 & \pm & 11.2 & - & & & & & \\
\hline $\mathrm{Na}$ & 10,000 & \pm & 50 & 10,340 & \pm & 2480 & - & & & & & \\
\hline $\mathrm{Ni}$ & 50.0 & \pm & 0.3 & 51.1 & \pm & 13.3 & 1000 & \pm & 5 & 1107 & \pm & 177 \\
\hline $\mathrm{Pb}$ & 25.0 & \pm & 0.1 & 25.1 & \pm & 10.5 & 100.0 & \pm & 0.5 & 94.6 & \pm & 30.3 \\
\hline $\mathrm{Si}$ & 5000 & \pm & 30 & 4663 & \pm & 700 & - & & & & & \\
\hline $\mathrm{V}$ & 50.0 & \pm & 0.3 & 44.6 & \pm & 10.7 & 100.0 & \pm & 0.5 & 89.9 & \pm & 18.0 \\
\hline $\mathrm{Zn}$ & 100 & \pm & 2 & 113 & \pm & 27 & 600 & \pm & 6 & 725 & \pm & 131 \\
\hline
\end{tabular}

Table 10. Content of elements in Soil reference materials by ICP-OES (treatment with boiling nitric acid).

\begin{tabular}{|c|c|c|c|c|c|}
\hline \multirow{2}{*}{$\begin{array}{c}\text { Reference Soil } \\
\text { Aterial } \\
\end{array}$} & \multirow{2}{*}{$\begin{array}{c}\text { Element } \\
\mathrm{Cu}\end{array}$} & \multirow{2}{*}{$\begin{array}{c}\begin{array}{c}\text { Certified Value, } \\
\mathbf{m g ~ k g}^{-\mathbf{1}}\end{array} \\
19.1\end{array}$} & \multicolumn{3}{|c|}{ Measured Value, $\mathrm{mg} \mathrm{kg}^{-1}$} \\
\hline & & & 22.3 & \pm & 6.7 \\
\hline \multirow{2}{*}{ SAZP-2011 } & $\mathrm{Mn}$ & 405 & 455 & \pm & 137 \\
\hline & $\mathrm{Ni}$ & 37.6 & 32.7 & \pm & 9.8 \\
\hline \multirow{5}{*}{ ILCS } & $\mathrm{Cr}$ & 24 & 20 & \pm & 6 \\
\hline & $\mathrm{Cu}$ & 42 & 41 & \pm & 12 \\
\hline & $\mathrm{Fe}$ & 44,200 & 38,000 & \pm & 11,000 \\
\hline & $\mathrm{Mn}$ & 181 & 188 & \pm & 56 \\
\hline & $\mathrm{Zn}$ & 124 & 121 & \pm & 36 \\
\hline \multirow{7}{*}{ SADPP-10/5 } & $\mathrm{Cd}$ & 0.35 & 0.43 & \pm & 0.13 \\
\hline & $\mathrm{Cu}$ & 28.6 & 32.9 & \pm & 9.9 \\
\hline & $\mathrm{Fe}$ & 18,917 & 18,675 & \pm & 5603 \\
\hline & Mn & 923 & 1072 & \pm & 322 \\
\hline & $\mathrm{Ni}$ & 39.3 & 36.4 & \pm & 10.9 \\
\hline & $\mathrm{Pb}$ & 13.6 & 11.0 & \pm & 3.3 \\
\hline & $\mathrm{Zn}$ & 55.9 & 59.2 & \pm & 17.8 \\
\hline
\end{tabular}

\section{Conclusions}

Thus, using three commercially available humates, we showed that HS has a complex inorganic composition compared to soils; however, HS sample preparation methods have their specifics due to HS features. A significantly higher organic fraction in HS than soils holds a different situation and, thus, requires particular approaches to HS decomposition preparations.

Five sample preparation approaches were tested: direct dissolution in water followed by centrifugation and without, boiling with nitric acid, microwave-assisted decomposition with nitric acid, and fusion with lithium metaborate. The main result is that the simultaneous quantification of all elements requires several decomposition techniques. Because of the chemical characteristics of As, B, Cd, Li, and S, the content of these elements cannot be reliably determined by fusion. Boiling HS with nitric acid is not informative for estimating the bulk metal content. 
In three commercially available preparations of coal humates, 31 elements were determined using ICP-AES (Ag, Al, As, B, Ba, Be, Ca, Cd, Co, Cr, Cu, Fe, K, Li, Mg, Mn, $\mathrm{Mo}, \mathrm{Na}, \mathrm{Ni}, \mathrm{P}, \mathrm{Pb}, \mathrm{S}, \mathrm{Sb}$, Se, Si, Sn, Sr, Ti, V, W, and Zn). All five sample-preparation methods can be used to determine $\mathrm{Ca}$ and $\mathrm{K}$ only. After decomposition by metaborate fusion, $\mathrm{Cd}, \mathrm{Pb}$, and $\mathrm{S}$ contents can be reliably determined after microwave-assisted decomposition with nitric acid and $\mathrm{P}, \mathrm{Si}, \mathrm{Sn}, \mathrm{Ti}, \mathrm{V}, \mathrm{W}$, and $\mathrm{Zn}$. Molybdenum can only be determined by sample dissolution in water without centrifugation. The rest of the elements can be determined by several methods. Thus, $\mathrm{Ba}, \mathrm{Na}$, and $\mathrm{Sr}$ can be determined by microwave-assisted decomposition and fusion; $\mathrm{As}, \mathrm{B}, \mathrm{Be}, \mathrm{Co}$, and $\mathrm{Li}$, can be determined by microwave-assisted decomposition or dissolution in water without centrifugation. Dissolution in water with and without centrifugation and microwave-assisted decomposition with nitric acid make it possible to determine the total $\mathrm{Cu}$. $\mathrm{Al}, \mathrm{Cr}, \mathrm{Fe}, \mathrm{Mg}, \mathrm{Mn}$, and $\mathrm{Ni}$ can be determined by dissolving in water without centrifugation, microwave-assisted decomposition with nitric acid, or fusion.

All three HS samples have the same qualitative elemental composition; however, the amount of some elements differs from the average for the samples: "Powhumus" has a higher content of As, Cr, Li, S, and Ti and "Sakhalin", Ba, Co, Cu, Sr, and W. The high content of mineral components was found in the samples "Powhumus" and "Sakhalin" (336 and $323 \mathrm{~g} \mathrm{~kg}^{-1}$, respectively). "Life Force" has $220 \mathrm{~g} \mathrm{~kg}^{-1}$ of mineral components. None of the determined concentrations of elements, except for arsenic, exceeds their maximum allowable concentrations.

In the analysis of HS solutions, the level of most bulk elements (excluding $\mathrm{Si}$ and $\mathrm{Al}$ ), especially those which are hazardous, such as $\mathrm{As}, \mathrm{Co}, \mathrm{Cr}, \mathrm{Ni}$, or $\mathrm{Mn}$, can be rapidly assessed without long sample preparation. However, some trace elements such as $\mathrm{Cd}, \mathrm{Cu}, \mathrm{Pb}, \mathrm{Sn}$, or $\mathrm{Sr}$ can be significantly underestimated. At the same time, microwave-assisted treatment of samples with concentrated nitric acid at $250{ }^{\circ} \mathrm{C}$ completely recovers $\mathrm{As}, \mathrm{Cd}, \mathrm{Cu}$, and $\mathrm{Pb}$, as well as $\mathrm{Li}$ and $\mathrm{B}$. Determination of bulk contents of $\mathrm{Al}, \mathrm{Si}, \mathrm{Ti}, \mathrm{V}$, and $\mathrm{W}$ is possible only after decomposition of an HS sample by dry ashing followed by metaborate fusion. We showed that the results of inorganic components of HS significantly depend on the sample preparation, especially in microcomponents. Therefore, HS total mineral composition, including both macro- and microcomponents, requires a combination of decomposition methods. These methodological findings can be extended to HS of other origins.

The methods selected in this study make it possible to reach characteristic ICP-AES detection limits for aqueous samples for most test elements, especially for major hazardous elements ( $\mathrm{As}, \mathrm{Cd}, \mathrm{Pb}$, and $\mathrm{Ni}$ ). However, the determination of $\mathrm{Ag}$, $\mathrm{Sb}$, and Se by selected approaches and ICP-AES is impossible.

Supplementary Materials: The following are available online at https://www.mdpi.com/article/ 10.3390/agronomy11122453/s1, Figure S1: The content of elements $\left(\mathrm{mg} \mathrm{kg}^{-1}\right)$ by different types of sample preparation approaches for "Powhumus", "Sakhalin", and "Life Force" HS: an aqueous colloidal solution of $\mathrm{HS}$ (Direct), fusion with $\mathrm{LiBO}_{2}$ (Ashing), an aqueous colloidal solution of HS followed by centrifugation (Centr), treatment with boiling nitric acid (Acid), treatment with nitric acid at $250{ }^{\circ} \mathrm{C}$ using a microwave autoclave (MW acid): $\mathrm{As}(a) ; \mathrm{B}(b) ; \mathrm{Ba}(c) ; \mathrm{Be}(d) ; \mathrm{Cd}(e)$; and $\mathrm{Co}(f)$. Figure S2: The content of elements $\left(\mathrm{mg} \mathrm{kg}^{-1}\right)$ by different types of sample preparation approaches for "Powhumus", "Sakhalin", and "Life Force" HS: an aqueous colloidal solution of HS (Direct), fusion with $\mathrm{LiBO}_{2}$ (Ashing), an aqueous colloidal solution of $\mathrm{HS}$ followed by centrifugation (Centr), treatment with boiling nitric acid (Acid), treatment with nitric acid at $250{ }^{\circ} \mathrm{C}$ using a microwave autoclave (MW acid): $\mathrm{Cr}(a) ; \mathrm{Cu}(b) ; \mathrm{Li}(c) ; \mathrm{Mn}(d) ; \mathrm{Mo}(e)$; and Ni (f). Figure S3: The content of elements $\left(\mathrm{mg} \mathrm{kg}^{-1}\right)$ by different types of sample preparation approaches for "Powhumus", "Sakhalin", and "Life Force" HS: an aqueous colloidal solution of HS (Direct), fusion with LiBO2 (Ashing), an aqueous colloidal solution of $\mathrm{HS}$ followed by centrifugation (Centr), treatment with boiling nitric acid (Acid), treatment with nitric acid at $250{ }^{\circ} \mathrm{C}$ using a microwave autoclave (MW acid): $\mathrm{Pb}(a) ; \mathrm{Sn}$ $(b) ; \mathrm{Sr}(c) ; \mathrm{V}(d) ; \mathrm{W}(e) ;$ and $\mathrm{Zn}(f)$. Figure S4: The content of elements $\left(\mathrm{g} \mathrm{kg}^{-1}\right)$ by different types of sample preparation approaches for "Powhumus", "Sakhalin", and "Life Force": an aqueous colloidal solution of $\mathrm{HS}$ (Direct), fusion with $\mathrm{LiBO}_{2}$ (Ashing), an aqueous colloidal solution of $\mathrm{HS}$ followed 
by centrifugation (Centr), treatment with boiling nitric acid (Acid), treatment with nitric acid at $250{ }^{\circ} \mathrm{C}$ using a microwave autoclave (MW acid): $\mathrm{Al}(a) ; \mathrm{Ca}(b) ; \mathrm{Fe}(c) ; \mathrm{Mg}(d) ; \mathrm{S}(e) ; \mathrm{Si}(f)$; and $\mathrm{Ti}(g)$. Figure S5: The content of elements $\left(\mathrm{g} \mathrm{kg}^{-1}\right)$ by different types of sample preparation approaches for "Powhumus", "Sakhalin", and "Life Force": an aqueous colloidal solution of HS (Direct), fusion with $\mathrm{LiBO}_{2}$ (Ashing), an aqueous colloidal solution of HS followed by centrifugation (Centr), treatment with boiling nitric acid (Acid), treatment with nitric acid at $250{ }^{\circ} \mathrm{C}$ using a microwave autoclave (MW acid): $\mathrm{K}(a) ; \mathrm{Na}(b)$; and $\mathrm{P}(c)$. $Y$-axis is in a $\log$ format. Figure S6: The content of major $(a)$ and minor (b) elements (in oxide forms) in the "Powhumus" HS sample. The total content of minor elements shown in diagram $b$ is $0.4 \%$ of the sample. Figure S7: The content of major $(a)$ and minor $(b)$ elements (in oxide forms) in the "Sakhalin" HS sample. The total content of minor elements shown in diagram $b$ is $0.3 \%$ of the sample. Figure S8: The content of major $(a)$ and minor $(b)$ elements (in oxide forms) in the "Life Force" HS sample. The total content of minor elements shown in diagram $b$ is $0.3 \%$ of the sample.

Author Contributions: Conceptualization, D.S.V. and M.A.P.; methodology, D.S.V.; software, E.A.K.; validation, E.A.K. and E.A.V.; formal analysis, E.A.K. and E.A.V.; investigation, E.A.K. and E.A.V.; resources, D.S.V.; data curation, E.A.K.; writing—original draft preparation, E.A.K.; writing—review and editing, D.S.V. and M.A.P.; supervision, D.S.V. and M.A.P.; project administration, D.S.V. and M.A.P.; funding acquisition, D.S.V. All authors have read and agreed to the published version of the manuscript.

Funding: This work was supported by The Russian Foundation for Basic Research, project number 20-33-70211.

Data Availability Statement: Not applicable.

Acknowledgments: This research was performed according to the Development program of the Interdisciplinary Scientific and Educational School of Lomonosov Moscow State University, "The future of the planet and global environmental change".

Conflicts of Interest: The authors declare no conflict of interest.

\section{References}

1. Trckova, M.; Matlova, L.; Hudcova, H.; Martin, F.; Zraly, Z.; Dvorska, L.; Beran, V.; Pavlik, I. Peat as a feed supplement for animals: A review. Vet. Med. 2005, 50, 361. [CrossRef]

2. Mendez, E.P.; Havel, J.; Patočka, J. Humic substances-compounds of still unknown structure: Applications in agriculture, industry, environment, and biomedicine. J. Appl. Biomed. 2005, 3, 13-24. [CrossRef]

3. De Melo, B.A.G.; Motta, F.L.; Santana, M.H.A. Humic acids: Structural properties and multiple functionalities for novel technological developments. Mater. Sci. Eng. C 2016, 62, 967-974. [CrossRef] [PubMed]

4. Pukalchik, M.; Kydralieva, K.; Yakimenko, O.; Fedoseeva, E.; Terekhova, V. Outlining the Potential Role of Humic Products in Modifying Biological Properties of the Soil-A Review. Front. Environ. Sci. 2019, 7, 10. [CrossRef]

5. Gašparovič, M.; Hrnčár, C.; Galik, B. The effect of feed additives in pheasants fattening: A review. J. Central Eur. Agric. 2017, 18, 749-761. [CrossRef]

6. Pandey, A.; Pandey, S.; Misra, V.; Devi, S. Role of humic acid entrapped calcium alginate beads in removal of heavy metals. J. Hazard. Mater. 2003, 98, 177-181. [CrossRef]

7. Schepetkin, I.; Khlebnikov, A.; Kwon, B.S. Medical drugs from humus matter: Focus on mumie. Drug Dev. Res. 2002, 57, 140-159. [CrossRef]

8. Winkler, J.; Ghosh, S. Therapeutic Potential of Fulvic Acid in Chronic Inflammatory Diseases and Diabetes. J. Diabetes Res. 2018, 2018, 1-7. [CrossRef]

9. Pant, K.; Singh, B.; Thakur, N. Shilajit: A humic matter panacea for cancer. Int. J. Toxicol. Pharmacol. Res. 2012, 4, 17-25.

10. Van Rensburg, C.J. The Antiinflammatory Properties of Humic Substances: A Mini Review. Phytother. Res. 2015, 29, 791-795. [CrossRef]

11. Van Rensburg, C.; Dekker, J.; Weis, R.; Smith, T.-L.; Van Rensburg, E.J.; Schneider, J. Investigation of the Anti-HIV Properties of Oxihumate. Chemotherapy 2002, 48, 138-143. [CrossRef] [PubMed]

12. Jooné, G.K.; Dekker, J.; van Rensburg, C.E.J. Investigation of the Immunostimulatory Properties of Oxihumate. Z. Für Nat. C 2003, 58, 263-267. [CrossRef]

13. Swat, M.; Rybicka, I.; Gliszczyńska-Świgło, A. Characterization of Fulvic Acid Beverages by Mineral Profile and Antioxidant Capacity. Foods 2019, 8, 605. [CrossRef] [PubMed]

14. Pandey, A.K.; Pandey, S.D.; Misra, V. Stability Constants of Metal-Humic Acid Complexes and Its Role in Environmental Detoxification. Ecotoxicol. Environ. Saf. 2000, 47, 195-200. [CrossRef] 
15. Perelomov, L.; Sarkar, B.; Sizova, O.; Chilachava, K.; Shvikin, A.; Perelomova, I.; Atroshchenko, Y. Zinc and lead detoxifying abilities of humic substances relevant to environmental bacterial species. Ecotoxicol. Environ. Saf. 2018, 151, 178-183. [CrossRef]

16. Sierra, J.; Roig, N.; Papiol, G.G.; Pérez-Gallego, E.; Schuhmacher, M. Prediction of the bioavailability of potentially toxic elements in freshwaters. Comparison between speciation models and passive samplers. Sci. Total. Environ. 2017, 605, 211-218. [CrossRef] [PubMed]

17. Bai, H.; Wei, S.; Jiang, Z.; He, M.; Ye, B.; Liu, G. Pb (II) bioavailability to algae (Chlorella pyrenoidosa) in relation to its complexation with humic acids of different molecular weight. Ecotoxicol. Environ. Saf. 2019, 167, 1-9. [CrossRef]

18. Bradl, H.B. Adsorption of heavy metal ions on soils and soils constituents. J. Colloid Interface Sci. 2004, 277, 1-18. [CrossRef] [PubMed]

19. Chassapis, K.; Roulia, M.; Tsirigoti, D. Chemistry of metal-humic complexes contained in Megalopolis lignite and potential application in modern organomineral fertilization. Int. J. Coal Geol. 2009, 78, 288-295. [CrossRef]

20. Borggaard, O.K.; Holm, P.E.; Strobel, B.W. Potential of dissolved organic matter (DOM) to extract As, Cd, Co, Cr, Cu, Ni, Pb and Zn from polluted soils: A review. Geoderma 2019, 343, 235-246. [CrossRef]

21. Qu, C.; Chen, W.; Hu, X.; Cai, P.; Chen, C.; Yu, X.-Y.; Huang, Q. Heavy metal behaviour at mineral-organo interfaces: Mechanisms, modelling and influence factors. Environ. Int. 2019, 131, 104995. [CrossRef] [PubMed]

22. Yang, F.; Tang, C.; Antonietti, M. Natural and artificial humic substances to manage minerals, ions, water, and soil microorganisms. Chem. Soc. Rev. 2021, 50, 6221-6239. [CrossRef] [PubMed]

23. Talpur, M.M.A.; Pirzada, T.; Ali, W.; Arain, M.H.; Rajper, S.; Khaskheli, M. Isolation and Characterization of Soil Fulvic Acid. Pak. J. Anal. Environ. Chem. 2016, 17, 8-17. [CrossRef]

24. Raspor, B.; Nürnberg, H.; Valenta, P.; Branica, M. Studies in seawater and lake water on interactions of trace metals with humic substances isolated from marine and estuarine sediments: I. Characterisation of humic substances. Mar. Chem. 1984, 15, 217-230. [CrossRef]

25. Hirata, S. Trace metals in humic substances of coastal sediments of the Seto Inland Sea, Japan. Sci. Total. Environ. 1992, 118, 325-333. [CrossRef]

26. Nriagu, J.O.; Coker, R.D. Trace metals in humic and fulvic acids from Lake Ontario sediments. Environ. Sci. Technol. 1980, 14, 443-446. [CrossRef]

27. Tsutsuki, K.; Kuwatsuka, S. Characterization of humin-metal complexes in a buried volcanic ash soil profile and a peat soil. Soil Sci. Plant Nutr. 1992, 38, 297-306. [CrossRef]

28. Santamaría-Fernández, R.; Cave, M.R.; Hill, S.J. The effect of humic acids on the sequential extraction of metals in soils and sediments using ICP-AES and chemometric analysis. J. Environ. Monit. 2003, 5, 929-934. [CrossRef]

29. Aster, B.; von Bohlen, A.; Burba, P. Determination of metals and their species in aquatic humic substances by using total-reflection X-ray fluorescence spectrometry. Spectrochim. Acta Part B At. Spectrosc. 1997, 52, 1009-1018. [CrossRef]

30. Hiraide, M. Heavy Metals Complexed with Humic Substances in Fresh Water. Anal. Sci. 1992, 8, 453-459. [CrossRef]

31. Shan, X.; Chen, B. Evaluation of sequential extraction for speciation of trace metals in model soil containing natural minerals and humic acid. Anal. Chem. 1993, 65, 802-807. [CrossRef]

32. Petronio, B.M.; Cosma, B.; Mazzucotelli, A.; Rivaro, P. A Multi Method Approach to Study Humic Compounds and Metal Speciation in Marine Sediment Samples. Int. J. Environ. Anal. Chem. 1993, 54, 45-56. [CrossRef]

33. Huljev, D. Interaction of some metals between marine-origin humic acids and aqueous solutions. Environ. Res. 1986, 40, 470-478. [CrossRef]

34. Huljev, D. Trace metals in humic acids and their hydrolysis products. Environ. Res. 1986, 39, 258-264. [CrossRef]

35. Guo, P.; Zhang, C.; Wang, Y.; Yu, X.; Zhang, Z.; Zhang, D. Effect of long-term fertilization on humic redox mediators in multiple microbial redox reactions. Environ. Pollut. 2018, 234, 107-114. [CrossRef]

36. Pham, D.M.; Kasai, T.; Yamaura, M.; Katayama, A. Humin: No longer inactive natural organic matter. Chemosphere 2021, 269, 128697. [CrossRef] [PubMed]

37. Zhang, C.; Zhang, D.; Xiao, Z.; Li, Z.; Suzuki, D.; Katayama, A. Characterization of humins from different natural sources and the effect on microbial reductive dechlorination of pentachlorophenol. Chemosphere 2015, 131, 110-116. [CrossRef]

38. Sánchez-Monedero, M.Á; Roig, A.; Cegarra, J.; Bernal, M.P.; Paredes, C. Effects of HCl-HF purification treatment on chemical composition and structure of humic acids. Eur. J. Soil Sci. 2002, 53, 375-381. [CrossRef]

39. Karpukhina, E.; Mikheev, I.; Perminova, I.; Volkov, D.; Proskurnin, M. Rapid quantification of humic components in concentrated humate fertilizer solutions by FTIR spectroscopy. J. Soils Sediments 2018, 19, 2729-2739. [CrossRef]

40. Balcke, G.U.; Kulikova, N.A.; Hesse, S.; Kopinke, F.-D.; Perminova, I.V.; Frimmel, F.H. Adsorption of Humic Substances onto Kaolin Clay Related to Their Structural Features. Soil Sci. Soc. Am. J. 2002, 66, 1805-1812. [CrossRef]

41. Ingamells, C. Lithium metaborate flux in silicate analysis. Anal. Chim. Acta 1970, 52, 323-334. [CrossRef]

42. Santos, M.C.; Nóbrega, J.A. Direct analysis of clay and refractory materials slurries by inductively coupled plasma optical emission spectrometry with axial viewing using the simplified generalized standard additions method. J. Anal. At. Spectrom. 2007, 22, 93-96. [CrossRef]

43. Volkov, D.S.; Proskurnin, M.A.; Korobov, M.V. Elemental analysis of nanodiamonds by inductively-coupled plasma atomic emission spectroscopy. Carbon 2014, 74, 1-13. [CrossRef] 
44. Chang, A.C.; Warneke, J.E.; Page, A.L.; Lund, L.J. Accumulation of Heavy Metals in Sewage Sludge-Treated Soils. J. Environ. Qual. 1984, 13, 87-91. [CrossRef]

45. Baláž, P.; LaCount, R.; Kern, D.; Turčániová, L. Chemical treatment of coal by grinding and aqueous caustic leaching. Fuel 2001, 80, 665-671. [CrossRef]

46. Bissen, M.; Frimmel, F.H. Arsenic-A Review. Part I: Occurrence, Toxicity, Speciation, Mobility. Acta Hydrochim. Hydrobiol. 2003, 31, 9-18. [CrossRef]

47. Frolova, L.N.; Kiseleva, T.L. Chemical composition of mumijo and methods for determining its authenticity and quality (a review). Pharm. Chem. J. 1996, 30, 543-547. [CrossRef]

48. Oria, M.; Harrison, M.; Stallings, V.A. (Eds.) Appendix J, Dietary Reference Intakes Summary Tables. In Dietary Reference Intakes for Sodium and Potassium; National Academies Press: Washington, DC, USA, 2019.

49. Dudka, S.; Miller, W.P. Accumulation of potentially toxic elements in plants and their transfer to human food chain. J. Environ. Sci. Heal. Part B 1999, 34, 681-708. [CrossRef]

50. Talar-Krasa, M.; Wolski, K.; Biernacik, M. Biostimulants and possibilities of their usage in grassland. Grassl. Sci. 2019, 65, 205-209. [CrossRef]

51. Guo, X.; Liu, H.-T.; Wu, S.-B. Humic substances developed during organic waste composting: Formation mechanisms, structural properties, and agronomic functions. Sci. Total. Environ. 2019, 662, 501-510. [CrossRef]

52. Olivares, F.L.; Busato, J.G.; De Paula, A.M.; Lima, L.D.S.; Aguiar, N.O.; Canellas, L.P. Plant growth promoting bacteria and humic substances: Crop promotion and mechanisms of action. Chem. Biol. Technol. Agric. 2017, 4, 30. [CrossRef]

53. Arif, M.; Alagawany, M.; Abd El-Hack, M.E.; Saeed, M.; Arain, M.A.; Elnesr, S.S. Humic acid as a feed additive in poultry diets: A review. Iran. J. Vet. Res. 2019, 20, 167-172. [PubMed] 